\title{
RECENT InCOME TAX DEVElopmentS
}

\section{ROCH MARTIN}

This article provides a summary of the civil penalties provisions of the Income Tax Act. While various warning cries have been directed at these provisions, their purpose and scope should not be ignored. The discussion is not intended to provide a detailed analysis; a working summary, consisting of legislative amendments and judicial developments, is the goal of this article. The Appendix contains possible applications of the provisions.
Cet article résume les dispositions relatives aux amendes administratives de la Loi de l'impôt sur le revenu. Bien que plusieurs alertes aient été sonnées à l'endroit de ces dispositions, leur objectif et portée ne doivent pas être ignorées. Le but de la discussion $n$ 'est pas de donner une analyse détaillée, mais plutòt de fournir un sommaire de travail comprenant des modifications et des élaborations de la loi. L annexe contient des applications éventuelles de ces dispositions.

\section{TABLE OF CONTENTS}

I. Legislative Amendments and Proposals $\ldots \ldots \ldots \ldots \ldots 19$

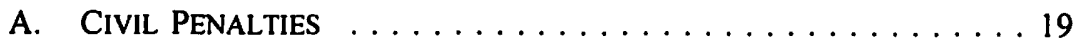

B. FOREIGN TAX CREDITS AND OIL AND

Gas PRoduction SHARING AgreEments $\ldots \ldots \ldots \ldots \ldots 31$

C. FOREIGN EXPLORATION AND DEVELOPMENT EXPENSES $\ldots \ldots 33$

II. JUdicial DEVELOPMENTS $\ldots \ldots \ldots \ldots \ldots \ldots \ldots \ldots \ldots \ldots \ldots$

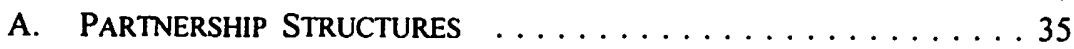

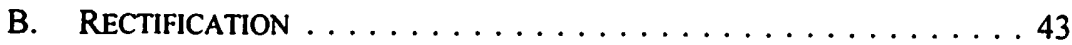

APPENDIX 1 IC 01-1 THIRD-PARTY CIVIL PENALTIES

- Draft January 12, $2001 \ldots \ldots \ldots \ldots \ldots \ldots$. . . . . . 47

APPENDIX 2 SECTION 163.2 OF INCOME TAX ACT (CANADA) . . . 75

APPENDIX 3 SPIRE FREEZERS STRUCTURE

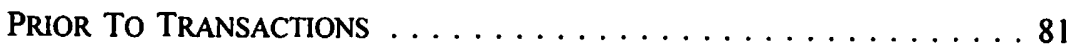

APPENDIX 4 SPIRE FREEZERS STRUCTURE AFTER TRANSACTIONS $\ldots 82$

\section{Legislative Amendments and Proposals}

\section{A. Civil Penalties}

\section{INTRODUCTION}

Section 163.2 of the Income Tax Act,' imposing civil penalties under certain circumstances, became law on June 29,2000 , and has been the source of much discussion and consternation among tax professionals. 
Bill C-25, ${ }^{2}$ or as it has become known, the Civil Penalties provision, provides a new tool to the Canada Customs and Revenue Agency's ("CCRA") arsenal of penalties available against individuals or firms ${ }^{3}$ who assist a taxpayer in planning or filing a "false statement."4

There has been a plethora of commentary ${ }^{5}$ and criticism provided to the Department of Finance regarding various drafts of these new provisions. Such criticism has warned of the legislation's over-inclusiveness and the potential for misuse by the CCRA, to the point that the Department of Finance has, on numerous occasions, taken defensive positions in its justification of the legislation. ${ }^{6}$

Among the warning cries, though, there are reasoned statements from critics that advise professionals such as lawyers and accountants not to lose sight of the scope and purpose of these new provisions. These critics suggest that where advice is consistent with the code of conduct and the ethics guidelines generally governing such professionals, such advice should not be subject to the civil penalties.

The following discussion is not intended to provide a detailed analysis of the new civil penalties as they may affect a tax specialist. Rather, this article summarizes the many analyses written to date by critics and provides a working summary of the new legislation to lawyers who may be involved in the implementation of tax motivated transactions.

An Act to amend the Income Tax Act, the Excise Tax Act, and the Budget Implementation Act, $2 \mathrm{~d}$ Sess., 36th Parl., 1999 (Royal Assent given 29 June 2000).

3 See discussion below regarding identities of those against whom this penalty may be used.

- See discussion below regarding what may constitute a "false statement."

5 For further discussion see: B.R. Carr \& G. Pereira, "The Defence Against Civil Penalties" (2000) 48:6 Can. Tax J. at 1737; B. Nichols, "Civil Penalties for Third Parties" (1999 Ontario Tax Conference, Toronto, Canadian Tax Foundation, 1999); B.R. Carr, J. Lalonde \& R. Neville, "The New Civil Penalty Proposals," 1999 Annual Tax Conference Report 18:1; C.R. McNary, "Civil Penalties - Professional Liability for Culpable Conduct", (2000 Prairie Provinces Tax Conference, Toronto, Canadian Tax Foundation, 2000); W.H.G. Heinrich, "The Tax Advisor at Risk: Civil Penalties and Criminal Sanctions," (1999 British Columbia Tax Conference, Toronto, Canadian Tax Foundation, 1999) [unpublished]; "Third-Party Civil Penalties," Draft Information Circular IC 01-I, dated January 12, 2001 (see Appendix 1).

Of particular note is a remark made by Jerry Lalonde, Assistant Director, Tax Legislative Division, Department of Finance, in a discussion among himself, Brian Carr, and Ralph Neville regarding "The New Civil Penalty Provisions" at the 1999 Annual Tax Conference, whereby Mr. Lalonde sought to relieve "firing line" criticism of the proposed draft legislation by reminding participants that involving the community of lawyers and accountants in the drafting of legislation to the level done here was unusual, and the Department would note concerns but not make changes to reflect every comment. Of particular note is Brian Carr's discussion, supra note 5, of the state of tax planning postenforcement of the new penalties and his suggestions of defences one might make if ever caught by the new provisions. However, there is still necessity for caution because the new legislation casts a very wide net, and there is no judicial interpretation to limit and interpret its parameters. 


\section{NeCESSity OF Civil PENAlties}

As early as 1992, the CCRA had noted several tax promotions that involved inflated asset values and what it considered "sham" business plans that were never carried out, and appeared to never have been intended to be carried out. ${ }^{8}$

In 1994 Revenue Canada conducted a project where it carefully scrutinized the actions of approximately 12,000 taxpayers and 40 tax preparers. That project resulted in the prosecution of 20 tax preparers under the criminal sanctions set forth in the Tax Act. ${ }^{9}$ As a result of the surprising number of prosecutions resulting from that project, in 1996 the Auditor General recommended that Revenue Canada seek amendments to the Tax Act to impose penalties, in addition to criminal penalties, on promoters of tax shelters and other arrangements, which it felt were abusive under the Tax Act. The recommended changes were proposed in draft legislation that was first released in September 1999. The draft legislation experienced several changes as it moved through the legislative process, finally receiving Royal Assent on June 29, 2000. ${ }^{10}$

The new legislation, though drafted more broadly than may be necessary to achieve its goals, is aimed primarily at two types of abuse. The first is found in s. 163.2(2) and involves promoters of tax motivated transactions that are not supported by the Tax Act but result in unwarranted claims for deductions. The second involves tax preparers who take it upon themselves to create or who acquiesce to the creation of unsupportable deductions in preparation of the returns. The second offence is described in s. 163.2(4) (collectively, the "New Civil Penalties").

Assuming it is unlikely that the intended readers of this article are likely to prepare tax returns, this discussion will focus primarily on the restrictions on tax planning found in s. 163.2(2), with only brief mention of false return prohibitions in s. 163.2(4).

\section{Global COMMUNications - TRIGgering CASE}

Tax professionals, such as lawyers and accountants, achieve a great deal of responsibility through self-governance. The freedoms and privileges of self-governance are earned and maintained by individual members of the profession safeguarding the respectability and reputation of the profession. Reputation is protected through ethical and careful practice and also by the profession's governing body taking responsibility to monitor practices and intervene where an individual's behaviour threatens the collective reputation of the profession. "Relying on this system, professional organizations have managed to restrict government regulation of professional conduct.

The history of s. 163.2 is described by Carr, Lalonde \& Neville, supra note 5 . The criminal provisions of the Tax Act are found in ss. 238 and 239.

$1 \quad$ See e.g., Alberta Code of Professional Conduct, Chapter 1, Commentary G.1. 
However, the New Civil Penalties provisions have the appearance of perhaps impinging upon professional regulation, which leads to the question as to why it was deemed necessary to legislate civil penalties while standards of professional conduct and ethics are in place. ${ }^{12}$

The income tax decision that caught the attention of the Department of Finance, and in large measure prompted the call for third party civil penalties, involved the valuation of seismic data purchased as Canadian exploration expense ("CEE"), which is 100 percent deductible. ${ }^{13}$ In Global Communications Limited v. The Queen, ${ }^{14}$ Global Communications Limited ("Global") purchased seismic data for $\$ 15$ million. The purchase price included a cash payment of $\$ 1.8$ million, and the $\$ 13.2$ million balance was secured by a limited recourse promissory note. Global claimed the $\$ 15$ million purchase price as CEE deductions over two years. The claim was reassessed, and the Minister disallowed the claim.

During the course of appeals, Global brought forth experts who provided opinions as to the value of the seismic data. The valuations, while between $\$ 15$ million and $\$ 19$ million, were viewed by the Federal Court of Appeal as suspiciously high because the data, along with additional seismic data, was sold in an arm's length transaction on the same day of the transaction for only $\$ 2$ million plus a right to fifty percent of licensing revenue for three years. Global lost its appeal. ${ }^{15}$

This case caught the attention of the Department of Finance for three reasons. First, the valuators gave unflinching opinions based on assumptions provided to them by the promoters of the arrangement where the assumptions were not based on facts. The valuators relied on the assumptions and representations of the promoters, even though, in the Minister's view, the assumptions given to them should not have passed the "smell test." Second, the promoters sold the tax shelter deal to their client, Global, based on the valuator's opinions that were, in the view of the Department of Finance, fabricated to suit the needs of the promoters of the deal. Each of the valuators and the promoters thought that they were sheltered in their participation in the scheme by being able to look to one another and claim reliance on information provided by the other. The promoters relied on the valuator's opinions, which were based upon assumptions provided by the promoters. The final reason this case raised concern, and the most shocking to the Department of Finance, was the supposed credibility of all parties involved in the scheme. The taxpayer, Global, is a reputable Canadian corporation, and the tax promoters who structured the deal were members of major law firms; that is, professionals who, in the Department of Finance's view, should have known that the scheme would fail. ${ }^{16}$

There has been much discussion and comment regarding the "slippery slope" that the civil penalties may create.

Subparagraph 66.1(6)(a)(i) of the Tax Act as it was then in force.

99 D.T.C. 5377 (F.C.A.), aff 97 D.T.C. 1293 (T.C.C.) [hereinafter Global].

For a more detailed discussion of the facts of the case and analysis by the courts, see Carr \& Pereira, supra note 5 at $1742-44$.

Ibid. at 1744 . 
The combination of factors present in the Global case, including reputable experts acquiescing to a transaction that should have made at least one of the participants question its validity, inspired the Department of Finance to take action to determine the extent of such transactions and legislate third party civil penalties to deter such practices.

\section{RECOMMENDATIONS FOR REFORM}

Canadian income tax law currently contains (i) civil penalties for taxpayers who make false statements and (ii) criminal penalties for taxpayers and tax advisors where the relevant actions are held to constitute tax evasion with intent. However, Revenue Canada found that pursuing criminal penalties for all cases of egregious behaviour on the part of tax advisors was administratively difficult, and it was impossible to target all perceived abuses using the criminal process. ${ }^{17}$ The burden of proof obviously rests with the Minister in pursuing criminal penalties, and the necessary investigations and trial preparation required in criminal prosecutions are too difficult to undertake, other than in extraordinary circumstances.

The Department of Finance became suspicious in the early 1990s that some tax professionals were of the view that potential consequences for the advisor were minimal, with the only restriction on behaviour being at a criminal threshold. As a result, while not acting on a level amounting to fraud, tax professionals could be very aggressive in their tax planning. ${ }^{18}$

Noting the perceived deficiencies in the tax legislation as it existed, the Auditor General, the House of Commons Standing Committee on Public Accounts (the "Committee") and the Technical Committee on Business Taxation (the "Mintz Committee") made separate recommendations to revise the Tax Act to impose civil penalties on tax advisors.

The Committee delivered their report to Revenue Canada and the Department of Finance in 1997. The Department of Finance then immediately referred the issue to the Mintz Committee to review the matter and make recommendations.

The Mintz Committee found that there was sufficient depth to the problem of tax advisors knowingly making false statements that they recommended in 1998 that the Tax $A c t$ be amended to include civil penalties enforceable against those who "knowingly or

18 Nichols, supra note 5 at $1: 18$. There has never been any implication by the Department of Finance or Revenue Canada that all tax professionals were being dishonest or fraudulent in establishing tax schemes. Rather, the emphasis of necessity for the New Civil Penalties has been that Revenue Canada needs some mechanism enabling it to deal with tax schemes that are not technically legally correct and that enforcement power would, hopefully, deter such tax planning. Of interesting note is that in 1996 the Auditor General reported that Revenue Canada's tax avoidance resources staff were stretched too thinly auditing tax shelters, and it was hoped that the threat of civil penalties on tax advisers would decrease the amount of marginal or incorrect schemes, thus relieving Revenue Canada's staffing problems. 
in circumstances amounting to gross negligence make false statements or omissions in respect of another person's tax matters." 19

The Committee reported that of approximately 325 tax shelters audited between 1993 and 1995, Revenue Canada found that most of such tax shelter schemes were, in its view, abusive. The Committee described an abusive tax shelter as one set up so that taxpayers are able to deduct losses in excess of the value of the underlying asset or the amount of risk incurred. ${ }^{20}$

Further, the Committee recommended not only that the Department of Finance introduce civil penalties, but that the Department do so immediately.

\section{Pre-Existing Penalties and Deterrents}

As briefly noted above, the various committees reviewing the issue of abusive tax shelter promoters identified the lack of civil penalties on tax preparers and advisors as deficient in the scheme of legislative deterrents previously existing in the Tax Act.

The Tax Act provides for criminal penalties where a person (either a taxpayer or a third party) is found guilty, beyond a reasonable doubt, of participating in a scheme that amounts to tax evasion. Until the amendments became effective in June 2000, civil penalties could only be imposed on a taxpayer where the taxpayer knowingly, or in circumstances amounting to gross negligence, made false statements or omissions in the filing of his or her own return. The civil penalties did not extend to anyone but the taxpayer.

As a result of the perceived gap that permitted tax advisors to be liable for only tax evasion meeting the criminal burden of proof, the Department of Finance believed there was an unfair balance of responsibility in favour of tax motivated arrangements that may be deficient but did not merit criminal penalties. ${ }^{21}$

Apart from the penalties in the Tax Act, there have always been standards and codes of ethics to which professionals must adhere. There has been discussion as to whether adherence to the respective Codes of Conduct for Chartered Accountants or to the respective Rules of Professional Conduct for lawyers is sufficient to ensure that a tax professional is not subject to the New Civil Penalties. ${ }^{22}$

Carr, Lalonde \& Neville, supra note 5 at 18:3.

Nichols, supra note 5 at $1: 9$.

See J. Lalonde, "Comments" (Annual Tax Conference 1999) [unpublished]. See also Nichols, supra note 5 at 1:8. For further discussion on the distinctions between "avoidance" and "evasion," see Heinrich, supra note 5, particularly as he discusses the continuing necessity for tax advisors and planners to assist their clients in minimizing the amount of tax they pay despite new threats on tax advisors.

Carr \& Pereira, supra note 5. 
The Department of Finance has commented publicly that "if you are complying with your professional code of conduct, it is very unlikely that you will ever come within spitting distance of these rules."23

However, Brian Nichols points out ${ }^{24}$ that this comfort, at least as it applies to the Rules of Professional Conduct of the Law Society of Upper Canada ("LSUC Rules"), is no comfort at all because the standard found in s. 163.2 is a higher standard of conduct than that imposed by the LSUC Rules. ${ }^{25}$

Chapter 1, Rule 1 of the Alberta Code of Professional Conduct (the "Alberta Rules") requires that "a lawyer must respect and uphold the law in personal conduct and in rendering advice and assistance to others." Commentary 1 to Rule I clarifies that this rule "is not intended to prevent a lawyer from advising a client who, in good faith and on reasonable grounds, desires to challenge or test a law through the violation of the law." Note that there is a proviso to this Commentary statement that a lawyer should assist a client in such a challenge only where it is the most effective means of achieving the client's objective and where the violation of law does not involve injury or material damage to any person or property.

It is important to draw the distinction between (i) aggressive tax planning and promotion of transactions where a lawyer and his or her client believes, in good faith, the transactions are technically correct; and (ii) the circumstances where an advisor and a client are "cooking the books" to create factual circumstances that fit within the law, such as Revenue Canada and the Court found to be the case in Global.

Further, in Draft Information Circular IC 01-1, issued January 12, 2001, and attached hereto as Appendix 1 (the "Circular"), the CCRA outlines certain guidelines that it will consider in the application of s. 163.2. In the discussion of Principle No. 8, the CCRA clarifies that the penalties are not intended to apply to activities that are "administratively acceptable to the CCRA as correct applications of law." They clarify that the penalties do not apply to advisors and planners who act honestly in discharging their professional responsibilities. It should be noted that this Circular is merely a draft, and that even when it is finalized, as an Information Circular, it will not be legally binding but will merely express the CCRA's administrative position at the time of its release.

The Department of Finance's comments regarding the following rules of professional conduct are, in fairness, most likely correct. However, until the courts establish a solid interpretation of s. 163.2, adherence to the rules deemed acceptable to the CCRA is a guessing game.

23 Carr, Lalonde \& Neville, supra note 5 at 18:10.

24 Nichols, supra note 5 at $1: 75$.

25 Mr. Nichols notes that while the LSUC Rules requiring a lawyer to not knowingly assist or encourage any dishonesty, fraud, crime or illegal conduct, the "culpable conduct" standard found in s. 163.2 is far more onerous than the standard set forth in the LSUC Rules. See discussion of "culpable conduct" below. 
While professionals, through self-governance and rules providing professional conduct guidelines, may not be impacted by the New Civil Penalty provisions, there are individuals involved in tax planning scenarios who are not subject to codes of ethics governing their conduct. More than just a warning to tax professionals to consider carefully the validity of tax plans and act within codes of conduct, the provisions of s. 163.2 are an attempt to fill a gap where some individuals may have previously escaped responsibility. ${ }^{26}$

\section{BRIEF OVERVIEW OF SECTION 163.2}

The text of s. 163.2, as enacted June 29, 2000, is attached as Appendix 2. Section 163.2(2), which specifically addresses tax planning, provides:

Penalty for misrepresentations in tax planning arrangements - Every person who makes or furnishes, participates in the making of or causes another person to make or furnish a statement that the person knows, or would reasonably be expected to know but for circumstances amounting to culpable conduct, is a false statement that could be used by another person (in subsections (6) and (15) referred to as the "other person") for a purpose of this Act is liable to a penalty in respect of the false statement.

\section{Prohibitive SubSeCtions and Penalties}

The New Civil Penalties target and prohibit two types of activities. The first relates to tax planning and the prohibitive language is found in s. 163.2(2) set forth above. The essential elements of this subsection are discussed in greater detail below.

An advisor violating s. 163.2(2) will be liable to the penalty described in s. 163.2(3). The minimum penalty is $\$ 1,000$. Where a tax planner or advisor provides advice and receives monetary compensation for that advice, the planner or advisor may be penalized the greater of $\$ 1,000$ or the total amount the planner receives for the advice and participation. ${ }^{27}$

Section 163.2(4) describes the second prohibited activity, which involves the preparations of returns and falsifying information in the returns of a taxpayer. For the purposes of this article, the discussion has been limited to tax planning activities.

Most notably, these provisions are broad enough to cover individuals or groups promoting or marketing tax shelter schemes through sales seminars, on the Web or through direct marketing. Prior to enactment of the New Civil Penalties provisions, unless the conduct of these individuals was criminal, there was no way for Revenue Canada to punish them for promoting unworkable schemes to their client "victims" who ended up bearing all loss if the scheme was reassessed and found to fail. Note that "gross entitlements" is defined in s. 163.2(1) as "all amounts to which the [advisor] ... is entitled, either before or after that time and either absolutely or contingently, to receive or obtain in respect of the activity." This definition can be interpreted to include not only fees, but disbursements. 


\section{8. "PERSONS"}

Sections $163.2(2)$ and $163.2(4)$ refer to "persons" who undertake prohibited activities. The definition in s. 163.2(1) does not limit, list or categorize what constitutes a "person" but merely states that a person includes a partnership.

It has been suggested that the Department of Finance likely has a profile of a "person" based on certain assumptions. ${ }^{28}$ Included in these assumptions are qualities of a "person" who (i) is receiving money for advice in relation to tax planning, (ii) seeks to advance their client-taxpayer's interests through promotion of a plan or scheme, (iii) provides advice on the making of a statement for tax purposes, and (iv) is not economically dependent on the taxpayer. ${ }^{29}$

However, while these traits include the planners and advisors who may be examples of "abusive" tax planners, the wording of ss. 163.2(2) and 163.2(4) does not limit the penalties to such persons, and thus the penalties may apply to any person, including officers or directors of a taxpayer, employees of the tax advisor or perhaps a person who buys or sells a business to a taxpayer. $^{30}$

One issue of particular concern for practitioners who are partners or employees of a partnership is, to what extent can the partnership be liable if an individual member or associate is subject to a penalty? Section 163.2(1) of the new legislative provisions defines a "person" as including a partnership.

While the CCRA has stated in the Circular that only those partners who perform the actions subject to the civil penalties will be assessed, there remain issues as to the extent of liability when a member of a partnership makes a false statement for the purposes of the New Civil Penalties. First, where the false statement is made by a single individual, there is no legislative clarity whether the penalty applies merely to that individual or whether the individual, as a member or employee of the partnership, will be considered sufficiently representative of the partnership to permit penalties to be assessed against the partnership. Limited liability partnerships are now relatively common and leads to the issue of whether an individual partner will be solely liable under these provisions.

A second concern has been raised with respect to the concept of imputed knowledge. Will a partner advising a client on tax matters be imputed to know all his client's commercial dealings, which may be handled by another partner of the firm, and which may have tax implications?

The foregoing discussion raises the issue of what is a reasonable level of due diligence to ensure that all the relevant facts are known to avoid making false statements. Where a professional is responsible for making accurate statements to the CCRA, it is incumbent 
upon the professional to go to certain lengths to determine if his statements are true. If that standard includes canvassing members of the firm, as is the case with respect to certain securities issues, then that practice may have to be implemented.

There are certain relieving provisions for clerical workers, as well as employees. Section 163.2(9) provides that a person who solely provides clerical services (other than bookkeeping services) or secretarial services is not considered to participate in the making of the false statement. Section 163.2(15)(b) states that "the conduct of the employee is deemed to be that of the [taxpayer] for the purposes of applying [civil penalties on taxpayers in] 163(2) to the [taxpayer]." The issue has been raised whether a tax manager of a corporate group may rely on the employee exception in respect of a false statement made by an affiliate of his employer. In the Circular the CCRA maintains that under such circumstances it would assess the employer; however, it admits that there is no specific exception for the employee in these situations. We understand that the Department of Finance is considering expanding the relief to employees exception to ensure an employee is not subject to penalty in respect of a false statement made by affiliate corporations, notwithstanding that such employee may not be employed by the particular affiliate.

\section{CRITICISMS OF THE TEXT OF THE LegisLATION}

The most common criticism of the text of s. 163.2 is that the language is so broad and inclusive that it is difficult to discern real guidelines of behaviour for tax professionals.

10.

\section{"Gross Negligence" vs. "Culpable Conduct"}

The text of both ss. 163.2(2) and 163.2(4) describe a knowledge standard for tax advisors such that where a person "knows, or would reasonably be expected to know but for circumstances amounting to culpable conduct" that a statement is false, that person is liable to a penalty. The legislative history of the words "culpable conduct" used in s. 163.2 indicate that those words were substituted to replace the original phrase "gross negligence."

The change was prompted by concerns raised by members of the CBA/CICA Joint Committee on Taxation (the "Joint Committee") in its discussions with the Department of Finance regarding a proposed draft amendment contained in the Federal Budget of February 6, 1999. The concern from the Joint Committee was that professionals should not be held liable for honest errors of judgment. "Culpable conduct" was chosen as the text that would be included in the new provisions to indicate a standard for conduct "that is tantamount to intentional acting, shows indifference as to whether the tax law is complied with or shows a wilful, reckless or wanton disregard of the law."3t

While replacing "gross negligence" with "culpable conduct" may have seemed a generous concession to the Joint Committee, there exists some case law suggesting that

31 Quote from a letter from Len Farber of the Department of Finance contained in Nichols, supra note 5 at 1:12. 
the "culpable conduct" standard is quite close to a "gross negligence" standard as that standard was applied to civil penalties assessed against taxpayers under s. 163(2). ${ }^{32}$

"Culpable conduct" must exist in the absence of actual knowledge of a false statement. Section 163.2(1) defines culpable conduct as follows:

Culpable conduct" means conduct, whether an act or a failure to act, that

(a) is tantamount to intentional conduct;

(b) Shows an indifference as to whether the Act is complied with; or

(c) shows a wilful, reckless or wanton disregard of the law.

The term "indifference" is quite subjective and presumably means a certain degree of wilful blindness. The CCRA has indicated that the "indifference standard" is considered to be greater than ordinary negligence. A similar standard may be useful to determine whether someone "shows a wilful, reckless or wanton disregard of the law." In the Circular the CCRA refers to a situation where a "reasonable, prudent person would know that his or her actions would result in a false statement but purposely continues with the chosen course of action."

\section{1. "FALSE StATEMENTS"}

The actions subject to penalties under ss. 163.2(2) and 163.2(4) include making, participating in, acquiescing in or causing another person to make a "false statement." "False statement" is defined in S. 163.2(1) to include "a statement that is misleading because of an omission from the statement."

While the burden of proof of the applicability of the New Civil Penalties lies with the CCRA, the general consensus is that this definition is drafted so broadly that it does not give clear guidelines to tax professionals as to what may or may not be subject to the New Civil Penalty provisions.

The counter-argument is that a "false statement" requires knowledge or fraudulent intent on the part of the person making the statement, which is a relatively high threshold and seems to conflict with the seemingly lower threshold for "culpable conduct" as discussed above. ${ }^{33}$ indifference as to whether the law is complied with or not." For further discussion, see Nichols, supra note 5 . 
Presumably, there will be continued debate until we have some established case law, as to what constitutes a false statement.

\section{Possible Effects of Third Party Civil Penalties}

The s. 163.2 penalties have placed tax advisors on guard. In addition to the monetary sanction, one issue is the possible chilling effect these provisions will have on aggressive tax planning. Will the CCRA overstep its bounds in application of these provisions by "policing" the Tax Act with enforcement mechanisms that are akin to criminal sanctions? $?^{34}$

Another issue relates to potential conflicts of interest between a tax professional and his or her client. ${ }^{35}$ If the CCRA determines that a false statement is made, that determination in most cases will have the effect of creating a conflict of interest between the client and the advisor, and an advisor's defence may inherently compromise the interest of the client.

Related to this issue is the fact that the evidence and information necessary to defend the advisor may be protected by solicitor-client privilege. ${ }^{36}$ In most tax-motivated transactions, a special effort is made to preserve solicitor-client privilege.

\section{SAFEGUARDS}

The Department of Finance has indicated that professionals who adhere to their professional conduct standards should not be subject to the New Civil Penalties. However, given the CCRA's condemnation of all those involved in the Global decision, it is difficult to assume that the CCRA would not consider imposing these penalties in similar circumstances irrespective that the applicable Law Society rules may not have been violated.

While the CCRA has stated it will not apply these provisions indiscriminately, ${ }^{37}$ the tax community is nervously waiting to see if the CCRA's administrative practice will follow its stated assurances. In the interim and until we have some judicial pronouncements, in addition to the minimum threshold of required compliance of the Law Society rules, the following should be considered:

- Engage in appropriate due diligence that permits you to give reasoned advice on the basis of knowledge of all the relevant facts. ${ }^{38}$

See Appendix 1. Principle No. 3 of Information Circular IC 01-1 specifically states that this legislation applies to tax advisors who are "willfully blind to obvious errors." 
- If you do not have technical knowledge to assess the correctness or possible correctness of a tax position, consult a tax professional or specialist.

- $\quad$ Contact your insurer to determine if your insurance covers penalties assessed under this new legislation. We understand insurers are presently considering these provisions.

In addition to the foregoing, it should be noted that, except in respect of tax shelter promotions, s. 163.2(6) provides for an exception to the New Civil Penalties for reliance in good faith on information provided to the advisor or because of such reliance, the advisor failed to verify, investigate or correct the information. "Good faith" is described in the Circular as "honesty of intention, and freedom from knowledge of circumstances which ought to put the holder on inquiry."

\section{B. Foreign Tax Credits and OIL and Gas Production Sharing Agreements}

To limit the impact of the application of Canadian and foreign taxes on the same income, Canada provides its residents with "foreign tax credits" for income or profits from taxes they have paid to another country. In most cases, it is clear whether a foreign tax is sufficiently similar to Canada's income tax to qualify for these credits. However, the characterization of a levy as an income tax is less clear with respect to certain levies imposed in some oil and gas producing countries.

The levies in question are imposed under "production sharing agreements" between the governments of the countries concerned (or their agents) and Canadian-residentcompanies. Under a typical production sharing agreement, the company undertakes to conduct exploration activities within a defined territory and, where the exploration efforts are successful, to develop the resource property and exploit it commercially. At the commercial exploitation stage, the resource production is divided between the company and the foreign government, often through a state-owned corporation, according to a sharing formula agreed to in the contract. Such formulas, which vary from contract to contract, typically grant the company enough of the resource production to cover its costs and to generate a profit. Production sharing agreements generally set out in detail how costs are to be recovered over time, what proportion of the production must be allocated to the state in any given year, and other key terms.

Most of the countries that enter into such agreements with Canadian companies also impose a corporate income tax. Rather than applying the tax separately, however, these countries integrate their income tax into the production sharing agreements themselves. In effect, part of the foreign government's share of the production under the agreement is characterized as a payment in satisfaction of the Canadian company's income tax liability to that government.

Because a production sharing agreement both allocates oil and gas production and incorporates the foreign country's income tax, it can be difficult to determine which portion of the foreign government's share is on account of an income tax. Indeed, the CCRA took the position that the Tax Act's current foreign tax credit rules may deny credit 
for any and all payments made pursuant to such agreements. The uncertainty Canadian companies face as a result can put them at a disadvantage relative to those foreign competitors whose domestic taxation rules provide foreign tax credits in similar circumstances.

The February 28, 2000, Federal Budget proposed amendments to the Tax Act to clarify the eligibility for a business foreign tax credit of certain payments made by Canadianresident taxpayers to foreign governments on account of levies imposed in connection with production sharing agreements. ${ }^{39}$ The proposed Amendments set out those circumstances in which a levy will be considered to be, in substance, an income tax paid by a taxpayer.

More specifically, the proposed Amendments require that, for a foreign levy to qualify, it must be computed by reference to net income, after recognition of relevant expenses, and must not be, under the agreement, either a royalty or any other consideration paid for the exploitation of the resource. Because the Amendments are intended to accommodate situations where the foreign income tax is calculated pursuant to a production sharing agreement, as opposed to being assessed separately, the proposed rules will apply only where the foreign country otherwise imposes what can be regarded as an income tax.

The amount eligible for a foreign tax credit cannot exceed 40 percent of the taxpayer's income from the business for the year and will be subject to the existing rules of the Tax Act governing the claiming of business foreign tax credits and the carry-overs of unused credits. ${ }^{40}$ The 40 percent rate is an approximation of the Canadian corporate rate and is the same proxy rate currently used for other foreign tax credit purposes.

The Amendments to the business foreign tax credit provisions of the Tax Act will also include specific rules for the recognition of a taxpayer's foreign exploration and development expenses (FEDE), discussed in the next section. While there already exists a general requirement in the Tax $A c t$ for taxpayers to recognize FEDE in computing the amount of foreign tax credit that can be claimed in respect of foreign source income, these rules will specify how FEDE will be allocated to a particular foreign country for purposes of claiming a foreign tax credit.

The new rules will apply to foreign income taxes paid by any given taxpayer pursuant to production sharing agreements in taxation years that began after the earlier of December 31, 1999, and a date chosen by the taxpayer (which cannot in any case be earlier than December 31, 1994).

14 Bill C-22, An Act to Amend the Income Tax Act, the Income Tax Application Rules, Certain Acts Related to the Income Tax Act, the Canada Pension Plan, the Customs Act, the Excise Tax Act, to Modernization of Benefits and Obligations Act and Another Act Related to the Excise Tax Act, Ist Sess., 37th Parl., 2001 (assented to 14 June 2001, S.C. 2001, c. 17) [hereinafter "Amendments"]. 


\section{FOREIGN EXPLORATION AND DEVELOPMENT EXPENSES}

A Canadian oil and gas or mining company that incurs foreign exploration and development expenses (FEDE) may claim a minimum 10 percent of its FEDE balance against its income from any source. A greater claim is permitted if a taxpayer's foreign resource income exceeds the 10 percent minimum.

\section{ISSUES}

The existing regime for FEDE raised a number of concerns with the Department of Finance.

First, there is no explicit requirement under the existing rules that FEDE be incurred by a taxpayer for the purpose of entitling the taxpayer to profits or gains in respect of any foreign resource property of the taxpayer. For example, some taxpayers have claimed FEDE even though a foreign affiliate of the taxpayer owns the foreign resource property to which the FEDE relates.

In addition, there are circumstances where FEDE expenses have been generated by virtue of a taxpayer resident in Canada acquiring resource property of little value from a debtor of the taxpayer in circumstances to which s. 79.1 of the Tax Act applies. The general effect of $s .79 .1$ is that a creditor acquires property seized from a debtor in default of a payment of a debt at a cost equal to the principal amount of the debt, but is not entitled to claim a capital loss or bad debt expense with regard to that debt. The application of s. 79.1 in this context was a particular concern where the debtor was not resident in Canada. This is because the parallel rules in $\mathbf{5 . 7 9}$, under which the debtor is generally deemed to have proceeds of disposition from the resource property equal to the principal amount of the debt, will not have any effect on the debtor's Canadian income tax.

Second, existing FEDE rules allow taxpayers to claim a FEDE deduction of up to the full amount of foreign resource income earned. In this respect, the Department of Finance felt FEDE rules were more generous than the rules permitting the deduction of Canadian development expenses and Canadian oil and gas property expenses. The FEDE rules also result in similar treatment for foreign exploration expenses as compared to Canadian exploration expenses, even though the one hundred percent write-off is an accelerated incentive rate, which the Department of Finance indicates was designed to encourage exploration activities in Canada, but not necessarily abroad.

Third, existing FEDE rules do not expressly apply on a country-by-country basis. Thus it is difficult to source FEDE deductions to a particular country in cases where a taxpayer incurs FEDE in connection with more than one country outside Canada. This issue is significant with regard to the calculation of a taxpayer's entitlement to foreign tax credits pursuant to the proposed new rules of production sharing agreements.

Also, the discretionary nature of the FEDE deduction may provide what the Department of Finance considered overly generous opportunities for maximizing foreign tax credit 
claims. This is because a FEDE deduction might be claimed in a taxation year for which little or no foreign business income taxes are paid, and not claimed in a taxation year for which large amounts of foreign business income taxes are paid. This action might be taken either to minimize the impact of the proposed 40 percent limit with regard to production sharing agreements, or minimize the effect of income-based restrictions in the existing foreign tax credit rules.

\section{PROPOSALS}

The February 28, 2000, Federal Budget proposed to introduce amendments to address all of the concerns of the Department of Finance, and draft amendments were tabled under Bill C-22.

\section{PROPOSED RESTRICTIONS ON FEDE DEFINITION}

With regard to outlays made by a person or partnership after February 27, 2000 (other than any outlay made pursuant to an agreement in writing entered into before February 28,2000 ), FEDE must relate to the acquisition of foreign resource property by the person or partnership or be made for the purpose of enhancing the value of foreign resource property owned or to be owned by the person or partnership.

Consistent with this new measure, s. 79.1 will not apply in connection with foreign resource property acquired after February 27, 2000, from a person (other than a person resident in Canada) or a partnership (other than a partnership each member of which is resident in Canada). These measures are aimed at ensuring that FEDE incurred by a taxpayer has the potential of directly generating income for the taxpayer that is subject to tax in Canada.

\section{Proposed Restrictions on Claiming of Post-2000 FEDE}

Post-2000 FEDE expenses will be allocated to separate pools on a country-by-country basis. Foreign resource income will be applied first to support global FEDE claims (i.e., FEDE claims generated under existing rules) and then, subject to a new limit equal to 30 percent of the FEDE balance in respect of a country, to support FEDE deductions in respect of the country to which the income relates. However, to the extent that the country-by-country limitation would cause a taxpayer's overall maximum FEDE deductions for a taxation year to be less than 30 percent of the total FEDE balances, the taxpayer will be permitted to augment the portion of a FEDE balance for a taxation year that may be claimed. The augmentations to FEDE deductions for specific countries in these circumstances are structured so that a taxpayer is allowed in aggregate to claim FEDE deductions for a taxation year totalling not more than the lesser of

- 30 percent of the total FEDE balances, and

- the taxpayer's total foreign resource income for the year. 
Taxpayers will have the flexibility as to which FEDE balance a deduction is claimed against. This is consistent with the approach taken with regard to the undepreciated capital cost of depreciable property. However, it is only after determining the amount of deduction against a FEDE balance generated by pre-200l expenses that it will be possible to determine deductions against FEDE balances generated by post-2000 expenses. All of these measures apply to taxation years that begin after 2000 .

\section{Allocation of FEDE fOR FOREIGN TAX CREDIT AND OTHER PURPOSES}

An FEDE deduction claimed for a taxation year that begins after December 31, 1999, (or after such earlier date as the taxpayer has elected to have the new production sharing agreement rules apply) will be explicitly required to be allocated to a specific country where the FEDE deduction relates to a pre-2001 FEDE balance. This rule is intended to apply primarily for the purpose of computing a taxpayer's foreign tax credit.

A taxpayer will be permitted to make reasonable assumptions as to which country or countries a particular deduction from a pre-2001 FEDE balance relates, provided that those assumptions apply consistently from year to year. If a taxpayer fails to make reasonable assumptions in this regard, the Minister of National Revenue will make reasonable assumptions that will be binding on the taxpayer.

\section{JUDICIAL DEVELOPMENTS}

\section{A. PARTNERSHIP STRUCTURES}

Partnerships are currently one of the most commonly used business structures in the oil and gas industry. Partnerships are very flexible and generally enable resource properties either to be acquired or distributed in a very tax efficient manner. Partnerships have also been the vehicle of choice to provide a tax efficient flow-through of income or deductions directly to the partners. As a result of their use and certain transactions that the CCRA has viewed as abusive, partnerships have been the subject of recent Supreme Court of Canada decisions.

\section{CONTINENTAL BANK LEASING CORPORATION V. M.N.R. ${ }^{41}$}

In Continental Bank the Supreme Court of Canada addressed the issue as to whether a partnership had been properly constituted in a tax motivated transaction. This wellreasoned and lengthy judgment has become one of the leading decisions for determining whether a partnership has been validly formed. Additionally, it stands for the proposition that the legal relationships among the parties will be governed by the agreements entered into by the taxpayers.

Continental Bank was in the process of winding up its affairs in 1986. Continental Bank owned a leasing subsidiary ("Subco") which was interested in disposing of certain leasing assets to an arm's length purchaser; however, the disposition would have resulted 
in recapture of depreciation, taxed as ordinary income. Subco thus formed a partnership with two subsidiaries of the purchaser. Subco then transferred most of its assets into the partnership under the rollover provisions of s. 97(2) of the Tax Act. Four days later, Subco was wound up into its parent, Continental Bank, and Subco's partnership interest was distributed to Continental Bank on a tax deferred basis pursuant to s. 88(1) of the Tax Act at a cost amount equal to Subco's elected amount under s. 97(2) of the Tax Act. Two days later, Continental Bank sold the partnership interest to subsidiaries owned by the purchaser. Continental Bank was not attempting to "bump" the tax basis of the assets, but to receive capital gains treatment on the gain rather than recapture of depreciation. In reassessing the transaction, one of the arguments advanced by the Minister was that a valid partnership had not been constituted by the parties because the transactions were in substance a sham. The Minister also argued that if a partnership had in fact been created, it was invalidated because the Bank $A c t^{42}$ prohibited a bank from holding, directly or indirectly, an interest in a partnership.

The second issue split the Supreme Court of Canada, with the majority concluding that the Bank Act breach did not invalidate the partnership. On the first point, the Supreme Court of Canada unanimously concluded that a partnership was created, notwithstanding the fact that the partnership agreement specifically contemplated that Subco and Continental Bank would continue as partners only until the sale was completed. Although Bastarache J. dissented on the Bank Act issue, he held that the partnership had been validly created at common law, and it is this finding in the judgment that provides much of the decision's precedential value.

In addressing the Minister's sham argument, Bastarache J. states that the sham doctrine will not be applied to invalidate a transaction unless there is an element of deceit in the way a transaction is structured or implemented. He relied upon the English Court of Appeal decision in Orion Finance Ltd. v. Crown Financial Management Ltd., ${ }^{43}$ wherein it was held that once documents are accepted as genuinely representing the transaction into which the parties have entered, the proper legal categorization of the relationship created is a matter of construction of the documents. As a result Bastarache J. essentially adopted a legal substance test that incorporates two elements: (i) examining the documents to determine whether the parties have satisfied the requirements of the legal relationship they have purported to create; and (ii) examining the facts to determine whether the agreement was acted upon and whether it actually governed the affairs of the parties.

Bastarache J. then reviewed the elements for creating a valid partnership: (a) a business; (b) carried on in common; and (c) with a view to profit. With respect to the first element, Bastarache J. held that a business had indeed been carried on, as Subco had transferred an existing business to the partnership and the leasing contracts associated with such business had continued during the short life of the partnership. This was the case even though it was noted that no new business was conducted and no meetings were held in the three-day period. On the issue of whether a view to profit existed, it was noted that the problem of ascertaining "a view to profit" is most difficult in those circumstances

[1996] 2 B.C.L.C. 78 [hereinafter Orion Finance]. 
where there is a real, albeit ancillary, profit element as opposed to those where there is not. Again citing the Orion Finance decision, Bastarache J. found that the fact that the partnership agreement contemplated the distribution of profits was objective evidence of the parties' intention to carry on business in common with a view to profit. This contention was not negated by the fact that Subco was not legally entitled to any profit from the partnership because it was not a partner at the partnership's fiscal year-end, nor did Bastarache J. consider the short duration of Subco's membership in the partnership to have any bearing on the issue. Furthermore, no importance was placed on the fact that the true objective of the series of transactions was to achieve a favourable tax result. Bastarache J. held:

Simply because the parties had the overriding intention of creating a partnership for one purpose does not, however, negate the fact that profit-making and profit-sharing was an ancillary purpose. This is sufficient to satisfy the definition in s. 2 of the Partnerships Act in the circumstances of this case. ${ }^{44}$

Bastrache J. then dismissed the Court of Appeal's rationale that a valid transaction should be invalidated solely because it is tax motivated. He held that a taxpayer who fully complies with the Tax Act should not be denied the benefit of such provisions simply because a transaction is motivated for tax planning purposes.

In two cases released March 1, 2001, the Supreme Court of Canada considered the question of whether a valid partnership had been established for income tax purposes. Both cases involved the acquisition of losses incurred in large real estate projects as income tax deductions. In one case a valid partnership was established, while in the other it was not. It is interesting that the judgment of the Court in each decision is written by Bastarache J., providing him with the opportunity to revisit the principles set out in the Continental Bank decision.

\section{BACKMAN V. M.N.R..$^{45}$}

The facts of Backman are relatively straightforward. A Texas limited partnership ("Texas Partnership") was created in 1985 by American residents in order to construct and operate an apartment complex. By 1988 the cost of the building and land on which it was situated far exceeded its fair market value, resulting in a large inherent loss. On August 29, 1988, the appellant and thirty-eight other Canadian individuals and an Alberta corporation received an assignment of partnership interest from the American partners for US $\$ 180,000$. The apartment complex was sold at fair market value to the former American partners, resulting in losses allocated to the new Canadian partners. Shortly after the sale of the apartment complex, the Texas Partnership acquired a 1 percent working interest in a Canadian oil and gas property for $\$ 5,000$. The oil and gas property never produced a profit, and production ceased shortly after its acquisition. Eighteen months later the Texas Partnership acquired a Montana condominium; however, the condominium never produced a profit. The Minister of National Revenue reassessed the Canadian individuals on the basis that a valid partnership had not been formed.

is [2001] 1 S.C.R. 367 [hereinafter Backman]. 
The Supreme Court of Canada dismissed the taxpayers' appeal. The Court first examined the essential ingredients of partnership and held that because the term "partnership" is not defined in the Tax Act, it is necessary to examine the provincial and territorial partnership statutes, which codify the common law and equity. The Court found that a taxpayer must first satisfy the definition of partnership that exists under the relevant provincial or territorial law. The Court further held that in computing income for purposes of s. 96 of the Tax Act, foreign partnerships also must satisfy the essential elements of a partnership under Canadian law.

Once again, the Supreme Court of Canada asserted that the three ingredients of a valid partnership are: (a) a business; (b) carried on in common; (c) with a view to profit.

With respect to the type of business that may be carried on, the Court stated that business includes "every trade, occupation and profession." The Court also stated:

The existence of a valid partnership does not depend on the creation of a new business because it is sufficient that an existing business was continued. Partnerships may be formed where two parties agree to carry on the existing business of one of them. It is not necessary to show that the partners carried on a business for a long period of time. A partnership may be formed for a single transaction. As was noted by this Court in Continental Bank, supra, at para. 48 , "[a]s long as the parties do not create what amounts to an empty shell that does not in fact carry on business, the fact the partnership was created for a single transaction is of no consequence." Furthermore, to establish the carrying on of a business, it is not necessary to show that the parties held meetings, entered into new transactions, or made decisions: Continental Bank, supra, at paras. 31-33. A business may be established even in circumstances where the sole business activity is the passive receipt of rent, as was noted by L'Heureux-Dube J. in Hillman Motors Lid. v. Canada, [1997] 2 S.C.R. 336, at para. 46:

\begin{abstract}
Where machinery is rented out, the essential core obligation may at times be limited to accepting rental revenue and assuming the business risk and other obligations. At any time during that period, any client could demand the execution of any of the contractual obligations, such as fixing an engine, for example. Where, because a rental business is fortunate enough to experience no mechanical breakdowns or accidents during a period of time, it "passively" accepts rental revenue and assumes business risk and obligations, it does not necessarily follow that it is not carrying on a business during that period. Holding otherwise would imply that rental businesses are "intermittent", that is, that they carry on a business only when something goes wrong in the operations. Such a proposition is unacceptable. ${ }^{46}$
\end{abstract}

The second essential ingredient is determining whether a business is carried on "in common." The required common purpose usually will exist where the parties enter into a valid partnership agreement setting out their respective rights and obligations as partners. Management of a partnership may rest with a single partner without derogating from the intention to carry on business in common. Bastarache J. stated: 
Other evidence consistent with an intention to carry on business in common includes: the contribution of skill, knowledge or assets to a common undertaking, a joint property interest in the subject-matter of the adventure, the sharing of profits and losses, the filing of income tax returns as a partnership. financial statements and joint bank accounts, as well as correspondence with third parties: see Continental Bank. supra, at paras. 24 and $36 .{ }^{47}$

The third essential element of partnership is a "view to profit." This determination requires an inquiry into the intentions of the parties. A distinction must be drawn between a motivation (what stimulates a person to act) and intention, which is the objective or purpose in acting. The Supreme Court of Canada has repeatedly held that a tax motivation does not derogate from the validity of transactions for tax purposes. ${ }^{48}$ Similarly, a tax motivation will not derogate from the validity of a partnership where the essential ingredients of a partnership are otherwise present. ${ }^{49}$ The issue becomes whether a taxpayer can establish an intention to make a profit, whether or not he was motivated by tax considerations.

A taxpayer's overriding intention is not determinative of whether the essential ingredient of "a view to profit" is present. It is sufficient for a taxpayer to demonstrate that there was an ancillary profit-making purpose. The Court stated:

\begin{abstract}
An ancillary purpose is by definition a lesser or subordinate purpose. In determining whether there is a view to profit courts should not adopt or employ a purely quantitative analysis. The amount of the expected profit is only one of several factors to consider. The law of partnership does not require a net gain over a determined period in order to establish that an activity is with a view to profit. For example, a partnership may incur initial losses during the start-up phase of its enterprise. This does not mean that the relationship is not one of partnership, so long as the enterprise is carried on with a view of profit in the future. Therefore, where a partnership is formed with the predominant motive of acquiring a tax loss, it is not necessary to show an intention to profit by the amount necessary to recoup the acquired losses or produce a net gain. ${ }^{50}$
\end{abstract}

As a result, "a view to profit" refers to an economic profit. Therefore, partners may have a view of profit where economically they will realize a profit from the date they become partners.

In determining whether a partnership in fact exists, courts must examine whether the objective, documentary evidence and the surrounding facts, including what the parties actually did, are consistent with a subjective intention to carry on business in common with a view to profit.

In applying the above principles to the facts and background, the Supreme Court of Canada held that the partnership agreement and other documents indicated an intention 
to form a partnership; however, the arrangement did not meet the prescribed tests, and therefore the favourable tax treatment of the losses that had been sought was denied. Given that a predetermined closing agenda provided that the apartment complex would be immediately sold to the original partner on purchase of the partnership by the Canadians, it was not reasonable to conclude that a profit motive existed with respect to the apartment complex. In addition, unlike the facts in Continental Bank, there was no continuity of business. The Court concluded that there was no evidence to indicate that there was an intention to make a profit during the short term the Canadians were involved with the apartment complex.

With respect to the acquisition of the oil and gas property, the Court held that while it did not constitute a sham, the purchase was "nothing more than window dressing." The taxpayer argued that there was an ancillary intention to carry on business with a view of profit by virtue of the purchase of the working interest in the oil and gas property. However, the Court was not convinced that the taxpayers had the necessary intention to carry on business in common with a view of profit:

The putative partners did not hold themselves out to others as providers of goods and services derived from their interest in the oil and gas property. They had no management duties in respect of the property. There is no evidence that the alleged partnership or its agents expended anything more than nominal time, attention or labour on the project; nor did they incur any liabilities to other persons in respect of it.

There was no evidence that a profit was ever realized, and no financial statements were produced. ${ }^{51}$

The Supreme Court of Canada also rejected the taxpayer's alternative argument that by virtue of the nature of a partnership as an independent and continuing entity, a person is capable of becoming a partner by acquiring an economic interest in the partnership even if he does not possess the intention to form a partnership relationship with others.

The Court held that in order for a person to become a partner by assignment there must be first a valid partnership at the time of entry of the new partner. The taxpayer must satisfy the essential ingredients of a partnership under Canadian law even in respect of foreign partnerships.

In summary, the Supreme Court of Canada concluded that there was no partnership because there was no business being carried on in common with a view to profit, and as a result, deduction of the tax losses was denied.

\section{SPIRE FREEZERS LTD. V. M.N.R. ${ }^{\mathrm{S2}}$}

The facts in Spire Freezers are very similar to those in the Backman decision and once again concern Canadian taxpayers who became partners in a US partnership that owned and developed luxury condominiums. However, in this case, with Bastarache and lacobucci JJ. writing once again for the Court, it was found that a valid partnership had 
been constituted and that the taxpayers were entitled to the business loss deductions they claimed.

In Spire Freezers, a California partnership ("California Partnership") was initially formed in 1978 by two equal United States corporations to develop a luxury residential condominium project. In order to obtain government approvals to construct the condominiums, the California Partnership was required to build a low-rent apartment building ("Tremont"), which was owned by a wholly owned subsidiary corporation. Appendix 3 sets forth the original structure. By the end of 1986 there was a large inherent loss of US $\$ 10$ million as a result of development costs far exceeding the fair market value of the projects. In the spring of 1987, several Canadian parties, including Spire Freezers, were advised of the opportunity to purchase the tax losses of the California Partnership at 20 cents on the dollar. On November 30, 1987, Spire Freezers and other Canadians acquired interests in the California Partnership, and the condominium project was sold at its fair market value to one of the original US partners, triggering an operating loss of US \$10.4 million. The California Partnership retained ownership of Tremont. Appendix 4 sets forth the ownership structure after the transactions. In summary, the Canadians paid US \$1.2 million to acquire Tremont and losses totalling US \$10.4 million. However, it is notable that the California Partnership continued to own and operate Tremont profitably for at least a decade. With respect to its 1987 taxes, the California Partnership claimed a large amount of losses, relating primarily to the sale of the luxury condominium project.

The Supreme Court of Canada referred to the Backman decision with respect to the analysis of whether a partnership exists for purposes of Canadian income tax law. The Court noted that the taxpayers admitted that the primary motivation for entering into the overall transaction was to take advantage of the existing tax losses. With respect to the luxury condominium project, it was held too briefly before being sold to say reasonably that a view to profit existed. However, the Tremont apartment building was the vehicle through which it was established that there was an ancillary purpose in the transaction that rendered the Canadians members of a valid partnership. In Backman, the interest in the oil and gas property was very small and required no management activities, and its acquisition did not represent a continuation of a pre-existing business. However, in Spire Freezers the property management business associated with the apartment building was pre-existing and continued by the Canadians. The Tremont apartment building required substantial management effort, which the appellants provided and from which they benefited by generating a profit for at least a decade. Additionally, during the transition period in which the Canadian investors shared ownership with the initial American partners, they ran the condominium project and Tremont as a business in common. All partners were associated in the management of the Tremont apartment building. It was restated that the time in which a partnership exists is not determinative and that a partnership, in fact, may be formed for a single transaction. Additionally, the quantum of the initial loss compared to anticipated profit does not negate the existence of a partnership. The Court held that despite the loss incurred on the sale of the condominium project, the fact that the Canadian partners were aware of the potential for profit from Tremont and the fact that Tremont consistently turned a profit over the years clearly 
established the business was carried on with a view to profit, even though the aggregate profits never exceeded the tax loss incurred in the year of sale of the condominium.

As a result, the Supreme Court of Canada held that the California Partnership had satisfied all of the necessary requirements set forth in Continental Bank to constitute a valid partnership.

\section{CONCLUSIONS}

As a result of these decisions there are several useful conclusions regarding the manner in which partnerships should be structured in order to survive future scrutiny by the CCRA:

(1) Structuring or entering a partnership where the taxpayer's primary motivation is to obtain tax benefits is not fatal, provided there is an ancillary view to profit.

(2) Ensure that all steps involved in the formation of a partnership are well-planned and properly documented with appropriate legal agreements.

(3) Ensure that the partnership and the partners actually conduct themselves in accordance with the partnership agreement and related documentation. Although the contracts are a fundamental factor, it is nonetheless imperative that the parties actually follow the terms of the agreements.

(4) In constituting a partnership with primarily a tax motivation, ensure that the ancillary "view to profit" actually exists and is reasonable. It appears that the "view to profit" requirement is not as stringent as the "reasonable expectation of profit" required in order to deduct expenses generally.

(5) It is important that the "business" requirement be satisfied in more than a cursory or convenient manner. A peppercorn may constitute adequate consideration for a contract in theory under the common law, but with respect to establishing the existence of a business being carried on, the taxpayer should ensure that the alleged business is reasonably considered as such.

(6) Assuming the essential elements of a partnership exist, the duration of the partnership and the income earned or losses incurred by the partnership are not determinative.

(7) In constituting the partnership, ensure that there are not any common law or statutory principles legally preventing the formation of the partnership. In addition, if investing in a different legal jurisdiction, ensure that the partnership otherwise qualifies as such under Canadian law.

(8) When taking an assignment of an interest from a partner in an existing partnership, ensure the partnership agreement and/or the applicable commercial 
law permit the withdrawal from the partnership without the automatic termination thereof.

\section{B. RECTIFICATION}

The ability to rectify contracts to reflect the clear intention of the parties has been challenged in a number of cases. The Minister is particularly compelled to challenge rectification where the rectification results in correcting inadequate tax planning, and thereby minimizing the taxes that would otherwise be payable by the taxpayer. However, there are several cases in which rectification has been permitted by the courts.

\section{DALE V. M.N.R. ${ }^{53}$}

One case in point is the decision in Dale. In Dale the taxpayers (a father and son) owned an apartment building situated in Halifax, which they had decided to sell in late 1985. Rather than simply transfer the building directly to a third party, they decided to convey it on a rollover basis under s. 85 of the Tax Act to a Prince Edward Island company, the Dale Corporation, of which they owned almost 90 percent of the shares. This was to avoid the recapture of depreciation and capital gains by the individuals on the direct disposition of the property, and this action was acknowledged by the Tax Court and the Federal Court of Appeal to be perfectly legitimate tax planning. In consideration for the transfer, Dale Corporation assumed the existing mortgage indebtedness on the building and issued to each of the taxpayers a preference share having a redemption value of almost $\$ 1.1$ million. Unfortunately, at the time of the transfer of the building and the alleged issue of the preferred shares, the Dale Corporation did not have preferred shares in its authorized capital, and therefore a shareholders meeting was held in order to approve the amendment to the capital. Even though the Registrar of Companies of Prince Edward Island had not yet issued the Supplementary Letters Patent that would formally recognize the change in the authorized capital, the Dale Corporation nonetheless issued the preferred shares.

Soon after the rollover of the building into the corporation, the Dale Corporation sold the building, realizing a capital gain and recaptured capital cost allowance. The Dale Corporation also declared capital dividends on the purported preferred shares. At the time that this was done all commercial legal steps had been adequately undertaken except for the requirement of the issue of the Supplementary Letters Patent. In 1988 the shareholders formally increased the authorized capital of the Dale Corporation, and continued into Nova Scotia. On that same day, they authorized an application to the Supreme Court of Nova Scotia under s. 109 of the Nova Scotia Companies $A c t^{54}$ to ratify the pre-existing rollover sale contract from 1985 .

Several years later, in 1991, the Dale Corporation obtained an order from the Supreme Court of Nova Scotia declaring that its authorized capital was amended retroactive to the rollover date and that the preferred shares were validly issued. The Minister alleged the 
preferred shares were not validly issued at the time of the rollover. On this basis the Minister included the capital gain and the recaptured capital cost allowance in the taxpayers' income. The Minister also included in their income, as a shareholder benefit, the capital dividends that the Dale Corporation declared on the preferred shares.

At trial the taxpayers were successful in their argument that the $\mathrm{s.} 85$ rollover was valid because of the promise to issue consideration shares and their subsequent issue within a reasonable period of time. However, the Court found the capital dividend to be a taxable benefit under s. 15(1) of the Tax Act, which the taxpayers appealed to the Federal Court of Appeal.

The Federal Court of Appeal determined that the order of the Nova Scotia Supreme Court was binding. Robertson J.A., for the Federal Court of Appeal, focused on the validity of this order. In determining whether a transaction will be recognized for tax purposes, it is necessary to look at statutory law, common law and equitable principles found in the jurisdiction in which the transaction took place. In this case the relevant legislation was the Nova Scotia Companies Act, which permitted the retroactive order requested. Robertson J.A. emphasized that the Minister must accept the legal results that flow from the proper application of a matter that falls within provincial law.

The Dale decision also relied upon an application of the rule against collateral attacks. Simply stated, this rule provides that an order of a superior court cannot be attacked collaterally unless it is lawfully set aside. Therefore, the order of the Nova Scotia Superior Court must receive full effect according to its terms, and it is binding on everyone, including the Minister.

Ultimately, the taxpayers were successful in appealing the inclusion of the capital gain, the recaptured capital cost allowance, and the shareholder benefit in their income. In the well-reasoned decision of Robertson J.A., it is clear that the Minister should not be permitted to attack the validity of an order with retroactive effect that is issued by a superior court until such an order is set aside. This case bodes well for taxpayers who seek to rectify an oversight or error in the execution of their tax planning and are permitted to do so in accordance with provincial laws.

\section{CANADA (A.G.) V. JULIAR}

The courts took an even more generous view of rectification in the case of Juliar. The case concerned a corporation that owned a convenience store in Niagara Falls, Ontario. The shareholders, a husband and wife, decided to transfer the business to their daughters and their respective husbands, being the Juliar and Roff families. The transfer was completed through the creation of a numbered corporation, 867871 Ontario Limited, which was owned in part by each of the Juliar and Roff families.

The corporation continued to grow, eventually owning seven convenience stores, but the Juliar and Roff families decided to split the business so that they could operate stores 
independently of each other, and therefore sought restructuring and tax advice from their accountants. It was apparently a fundamental concern in this reorganization that it be accomplished without adverse tax effects. Thus the Juliars and Roffs each incorporated new corporations and transferred assets to each of them, which transaction was sought to be accomplished on a tax-deferred rollover basis under s. 85 of the Tax Act. The Roffs received preferred shares in their newly-incorporated company in exchange for their shares of 867871 Ontario Limited, but the Juliars instead took back promissory notes, on the advice of their accountant. The accountant based his conclusions on his erroneous understanding that when the parents had transferred the shares to their daughters, that their cost bases had been increased at that time, even though this was not the case.

Receiving a promissory note rather than shares as consideration resulted in the Juliars being subject to tax on the deemed dividend they received pursuant to s. 84.1 of the Tax $A c t$, although the Roffs were not affected because their rollover had complied with the provisions of $\mathrm{s}$. 85 . This income tax liability was clearly not anticipated nor desired by the Juliars. The Juliars applied to the Ontario Superior Court of Justice ${ }^{56}$ for an order rectifying the transaction in order to transform it into an exchange of the shares of the holding company for shares of the transferee company. In this case, the taxpayer served notice of the application on the Minister.

The Ontario Court of Appeal upheld the determination by the Ontario Superior Court that rectification should be allowed. It agreed wholeheartedly with the reasoning of the lower Court in determining that the true agreement between the parties was to acquire a partial interest in the holding company by transferring shares in the holding company to the second company in a way that would not attract immediate tax liability. The trial judge had relied on the evidence given that if there was tax liability, there would have been no transaction.

The following passage is useful for taxpayers seeking a rectification order:

It is a fact of modern day commercial life and high tax rates that tax consequences are an essential consideration in most commercial transactions. Adverse tax consequences are often a "deal breaker" to effecting the transaction. Division of a family business among the children of the founder of the business is not an uncommon occurrence and is invariably intended to be effected with little or no cash and on a basis that does not attract immediate liability for income tax. A liability for tax would deprive either the taxpayer or the business of cash and its earning opportunities or force a sale of productive assets to realize the cash necessary to pay the tax..$^{57}$

The Court of Appeal also turned to the general principles of rectification and found that the facts fell squarely within the rules of rectification. The basic principle is that rectification can apply when the document does not carry out the intentions of the parties. Also there is no reason to refuse rectification of a document where the sole purpose of seeking the rectification is to allow the parties to obtain a legitimate fiscal advantage, 
provided this was their common intention at the time of executing the document. The Court used these encouraging words:

[No case] contains anything which compels the court to the conclusion that rectification of a document should be refused where the sole purpose of seeking it is to enable the parties to obtain a legitimate fiscal advantage which it was their common intention to obtain at the time of the execution of the document. ${ }^{58}$

This favourable decision should be carefully applied on the basis that the Court did acknowledge that rectification should be ordered cautiously and infrequently. The scope of the possible application of rectification orders is a serious concern to the CCRA. This is apparent from the CCRA's opposition to the court action in Juliar. Prior to the release of the Ontario Court of Appeal decision in Juliar, the CCRA stated its position regarding opposition to rectification orders. ${ }^{59}$ The CCRA appears to identify two types of cases. First, those situations where the documents do not reflect the parties' intention; the Dale case is an example. The second category includes cases where the tax result flowing from a "done deal" is not agreeable to the taxpayer and motivates the application for rectification. In the CCRA's opinion, Juliar is an example of the second category. In the second type of case, taxpayers can expect the CCRA to oppose any application for rectification. Taxpayers must be prepared to prove that the tax result of a transaction was an integral part of their "original and continuing" intention. 


\title{
APPENDIX $1^{*}$
}

\author{
IC 01-1 \\ Third-Party Civil Penalties - DRAFT \\ JANIARY 12, 2001
}

\section{Introduction}

1. This information circular outlines the Canada Customs and Revenue Agency's guidelines and processes for the application of the third-party civil penalties in section 163.2 of the Income Tax Act (ITA) and section 285.1 of the Excise Tax Act (ETA). The term "taxpayer" used within this circular also applies to "registrant" under the ETA.

2. The Canadian tax system is based on the principle of self-assessment. Taxpayers are responsible for filing their tax returns accurately, truthfully, and on time. Tax legislation contains various measures to encourage compliance, including penalties for taxpayers who provide false or misleading information relating to tax matters. However, prior to enactment of the third-party civil penalties which came into force on June 29,2000 , there was no civil penalty provision that applied to those who counsel others to file their returns based on false or misleading information.

3. The objective of the third-party civil penalties is to deter third parties from making false statements or omissions in relation to income tax or GST/HST matters. These penalties are directed at ensuring tax compliance and deterring inappropriate behaviour.

4. The Canadian tax system has benefited from a cooperative relationship between professional advisors and Canada's tax administration, the Canada Customs and Revenue Agency (the CCRA). Since that relationship is critically important to all Canadians, and to the continued health of our taxation system, the CCRA is committed to applying the penalties fairly, consistently and only when clearly justified. The CCRA recognizes that tax professionals have a responsibility to act in the best interests of their clients and this includes the right to minimize their tax liability within the law.

\section{Principles of Application}

5. Given the stated purpose of the third-party civil penalties, administrative principles have been formulated to ensure that the penalties are applied in a fair and reasonable way. These principles are as follows:

This version of "Third-Party Civil Penalties" was taken from the Canada Customs and Revenue Agency web site on 12 January 2001. Information Circulars are updated and revised by the CCRA on an ongoing basis. For a current version see IC $0 \mathrm{l}-1$ "Third-Party Civil Penalties," online: Canada Customs and Revenue Agency <www.ccra-adrc.gc.ca/E/pub/tp/ic01-leg/icØ1-1-e.pdi> (date accessed: 19 December 2001). 
PRINCIPLE NO. 1

6. The legislation is intended to apply mainly to arrangements and plans that contain false statements, often without the knowledge of the client. These are marketed typically as tax shelter and tax-shelter like arrangements that may be defective because of overvaluations of property, excessive or inflated costs, or lack of actual or intended business activity. Tax-shelter like arrangements are those arrangements that do not fit into the definition of a "tax shelter" in subsection 237.1(1) of the ITA, but they provide similar tax benefits.

\section{PRINCIPLE NO. 2}

7. Tax-planning arrangements that comply with the law are not affected by these penalties. The legislation is intended to apply to those advisors, tax return preparers and promoters who make (or participate in the making of) false statements knowingly or in circumstances amounting to culpable conduct. Such behaviour goes beyond the bounds of the law in search of a result that under-reports tax payable or overstates a refund or rebate claim. The legislation is designed to ensure the integrity of the tax law by deterring inappropriate behaviour.

\section{PRINCIPLE NO. 3}

8. The legislation is intended to apply to those tax return preparers and advisors who counsel and assist others in making false statements when they file their returns. It also applies to advisors and tax return preparers who are wilfully blind to obvious "errors" when preparing, filing or assisting a taxpayer in filing a return.

\section{PRINCIPLE NO. 4}

9. The legislation is not meant to impede regular day-to-day business activities and conventional tax-planning involving the application of the law to issues such as estate freezes, rollovers, reorganizations, amalgamations and owner/manager remuneration. These activities will not be impeded as long as they do not contain a false statement made knowingly or with culpable conduct.

\section{PRINCIPLE NO. 5}

10. The legislation is not intended to apply to honest mistakes, oversights and errors in judgment. Evidence concerning a person's conduct will be gathered to determine whether the error was made honestly (with good faith) or dishonestly (with bad faith, or with a wilful, reckless or wanton disregard of the law).

\section{PRINCIPLE NO. 6}

11. The legislation is not intended to apply to differences of interpretation where a reasonable argument (an argument that is not obviously wrong) exists as to the 
application of the law. The case law will often indicate whether such an uncertainty exists.

12. Similarly, the penalty would not be applied to honest differences of opinion on such issues as:

- capital expenditures vs. repairs;

- capital gains vs. income;

- personal vs. business expense determinations; and

- taxable status of a particular good or service for GST/HST purposes.

Issues such as these have been traditional sources of disagreement. However, application of the penalty will be considered where an interpretative position is taken that is clearly contrary to the established industry practice, the Agency's public position, or the case law, and for which no reasonable argument can be made.

\section{PRINCIPLE NO. 7}

13. The legislation is not intended to create additional audit or verification work for accountants and lawyers who conduct their affairs in accordance with their professional standards. Advisors and tax return preparers are entitled to rely in good faith on information provided to them by a client, or another person acting on the client's behalf, that is not obviously incorrect, misleading or contradictory to other information. However, this reliance in good faith does not apply to a person who is also selling or promoting tax shelters or tax-shelter like arrangements, since this is defined as an excluded activity (explained in paragraphs 38 to 40 ) in the legislation.

\section{PRINCIPLE NO. 8}

14. These penalties are not intended to apply to activities that are administratively acceptable to the CCRA as the correct application of the law. Examples include paying a bonus to the principal shareholder-manageror other key employees to reduce small business income to the Small Business Deduction limit; and making an immaterial adjustment to a GST/HST return for a filing period which is subsequent to the filing period in which the transaction giving rise to the adjustment took place.

15. In summary, the legislation is designed to deter inappropriate behaviour. These principles of application will be the gauge against which behaviour will be considered. The penalties do not apply to those advisors and planners who act honestly in discharging their professional responsibilities. Since substantially all professionals act responsibly, it is expected that very few will ever be faced with a third-party penalty assessment. It is in the joint interests of both the CCRA and tax professionals that the inappropriate behaviour addressed by these penalties must not be condoned. 


\section{THE LAW}

16. The legislative structures under section 163.2 of the ITA and section 285.1 of the ETA are very similar. For each subsection under section 163.2 of the ITA there is a corresponding subsection under section 285.1 of the ETA. Therefore, as a general rule, this circular will refer to the relevant subsection or paragraph only. For example, subsection 163.2(2) of the ITA and subsection 285.1(2) of the ETA will be referred to as subsection (2) of each Act. Where there are differences between the two Acts, a complete reference will be given and the differences will be discussed.

17. Both section 163.2 of the ITA and section 285.1 of the ETA provide for two penalties, one directed primarily at those who prepare (or participate in), sell or promote tax shelters or tax-shelter like arrangements; and the other directed at those who provide tax-related services to particular taxpayers. The first of these two penalties will be referred to as the "planner penalty" and the latter will be referred to as the "preparer penalty" for the rest of this circular.

\section{PLANNER PENALTY}

18. Subsection (2), the planner penalty, provides for a penalty on a person who makes, furnishes, participates in the making of, or causes another person to make or furnish a statement that the person knows, or would reasonably be expected to know but for circumstances amounting to culpable conduct, is a false statement that could be used by another person for a purpose of the ITA/ETA. Unlike the preparer penalty (defined in paragraph 20), the person who could use the false statement does not need to be identified in order to apply this penalty. Examples of when this subsection could be applicable are:

- tax-shelter promoters holding seminars or presentations to provide information in respect of a specific tax shelter; and

- appraisers and valuators preparing a report for a proposed scheme/shelter that could be used by unidentified investors.

\section{PENALTY AMOUNT}

19. Subsection (3) provides that the penalty to which a person is liable under subsection (2) for a false statement is $\$ 1,000$. However, when a false statement is made in the course of a planning activity or a valuation activity, the penalty amount is the greater of $\$ 1,000$ and the total of the person's gross entitlements for the planning or valuation activity (calculated at the time at which the notice of assessment of the penalty is sent to the person).

\section{TAX-RELATED SERVICES (PREPARER) PENALTY}

20. Subsection (4), the preparer penalty, provides for a penalty on a person who makes, or participates in, assents to, or acquiesces in the making of a statement to, by or on 
behalf of another person that the person knows, or would reasonably be expected to know, but for circumstances amounting to culpable conduct, is a false statement that could be used by or on behalf of the other person for a purpose of the ITA/ETA. Subsection (4) would be applicable to the tax return preparer for each investor or taxpayer that can be identified. Examples would include:

- a tax preparer preparing a tax return for a specific taxpayer;

- a tax advisor providing tax advice to a specific taxpayer; and

- an appraiser or valuator preparing a report for a specific taxpayer or a number of persons who can be identified.

\section{PENALTY AMOUNT}

21. For a penalty levied under the ITA, subsection $163.2(5)$ provides that the penalty to which a person is liable under subsection (4) in respect of a false statement is the greater of:

(a) $\$ 1,000$, and

(b) the lesser of:

(i) the penalty to which the other person (i.e. the person who could use the false statement for a purpose of the ITA) would be liable under subsection 163(2) if the other person made the statement in a return filed for the purposes of this Act and knew that the statement was false; and

(ii) the total of $\$ 100,000$ and the person's gross compensation, at the time at which the notice of assessment of the penalty is sent to the person, for the false statement that could be used by or on behalf of the other person.

22. For a penalty levied under the ETA, subsection $285.1(5)$ provides that the penalty to which a person is liable under subsection (4) in respect of a false statement is the greater of:

(c) $\$ 1,000$, and

(d) the lesser of:

(i) the total of $\$ 100,000$ and the person's gross compensation, at the time at which the notice of assessment of the penalty is sent to the person for the false statement; and

(ii) $50 \%$ of the decrease in the tax liability or increase in the net refund or rebate claim caused by the reporting of a false statement by the other person. 
23. Subsections (2) and (4), the planner and the preparer penalties, could both apply to the same false statement. However, subsection (14) provides that a person who is liable to pay penalties under both subsections (2) and (4) for the same false statement is required to pay penalties that are not more than the greater of the penalty under subsection (2) and the penalty under subsection (4). Examples would include:

- a broker remunerated for promotional presentations of a tax shelter that is used by investors that can be identified; and

- tax planners, appraisers and/or valuators preparing a report for a proposed scheme/shelter that is used by investors who can be identified.

\section{Interpretation and Discussion}

\section{FALSE STATEMENT}

24. A false statement is an incorrect statement, including a statement that is misleading because of an omission from the statement, regardless of whether the person making, participating in, or assenting to the making of, the statement has any intention to deceive. However, in order for the third-party civil penalties to be considered, a person must know, or be reasonably expected to know, but for circumstances amounting to culpable conduct, that the statement is a false statement that could be used for a purpose of the ITA/ETA. The meaning of a false statement is also modified by subsection (8) to deem two or more false statements to be one false statement in cases when there is one or more planning activities that relate to a particular arrangement (such as a tax shelter, a tax-shelter like arrangement or flowthrough shares) or a valuation activity that relates to a particular property or service. This deeming provision does not apply to subsections (4) and (5), the preparer penalty.

\section{STATEMENT}

25. "Statement" includes an oral or documentary representation. Examples include information provided on: tax returns, election forms, correspondence, invoices, donation receipts, statements, valuation reports, certifications, financial statements and their notes, contracts, prospectuses, selling documents, and other publications.

\section{CULPABLE CONDUCT}

26. "Culpable conduct" must be present in the absence of actual knowledge of a false statement, in order for the third-party civil penalties to be considered. Culpable conduct refers to conduct that is not simply an honest error of judgement or failure to exercise reasonable care (i.e., ordinary negligence). It refers to conduct (an act or a failure to act) that is tantamount to intentional conduct, shows an indifference as to whether the ITA/ETA is complied with, or shows a wilful, reckless or wanton disregard of the law. 


\section{TANTAMOUNT TO INTENTIONAL CONDUCT}

27. The expression "tantamount to intentional conduct" in the definition of culpable conduct means conduct that is equal in effect, to intentional conduct, i.e., a person's conduct (an act or failure to act) shows that the person must have intended to make (or participate in or assent to the making of) a false statement.

\section{INDIFFERENCE}

28. The expression "shows an indifference as to whether this Act is complied with" in the definition of culpable conduct describes the passive aspect of culpable conduct. The expression means that the person's actions or failure to act indicate that the person was wilfully blind regarding the application of the tax legislation. The person suspects that the situation demands that certain questions be asked. However, inquiries are not made because that would fix the person with knowledge. This behaviour was addressed in Sirois (L.C.) v. Canada, 1995 Carswell Nat 555, [1995] 2 C.T.C. 2648 (TCC) which relates to subsection 163(2) of the ITA, gross negligence on the part of the taxpayer. The court described the taxpayer's behaviour as "He buried his head in the sand."

29. The "indifference standard" is considered to be greater than ordinary negligence. It is more or less equivalent to the standard used to measure the purposeful act of wilful, reckless or wanton disregard of the law. As stated in Gerald Malleck v. Her Majesty the Queen, 98 DTC 1019 (TCC) at page 1021 "There is, however, little, if any, difference between approaching the "willful, the reckless, the wanton", and "indifference as to whether the law is complied with or not"."

\section{WILFUL, RECKLESS, OR WANTON DISREGARD OF THE LAW}

30. The expression "shows a wilful, reckless or wanton disregard of the law" in the definition of culpable conduct points to the situation where a reasonable, prudent person would know that his or her actions would result in a false statement but purposely continues with the chosen course of action. For example, an accountant would reasonably be expected to have knowledge of a particular issue that was dismissed at the Supreme Court level but decides to file on a basis that disregards the findings of that Court. The accountant would be demonstrating wilful or wanton disregard of the law if he or she counsels a filing position that is clearly contrary to the Supreme Court decision.

\section{PARTICIPATE}

31. The definition of "participate" includes causing a subordinate to act or to omit information; and to know of, and to not make a reasonable attempt to prevent, the participation by a subordinate in an act or omission of information. 


\section{SUBORDINATE}

32. The definition of "subordinate" relating to a particular person includes not only employees, but also other persons over whose activities the particular person has direction, supervision or control. For example, if a particular person provides directions to, supervises or controls the activities of another person who is not an employee of the particular person, the other person would be considered to be a subordinate of the particular person for the purpose of determining whether the particular person participated in making a false statement. This provision may apply in a situation where a promoter, advisor or tax return preparer carves out certain activities relating to the making of a false statement and subcontracts these activities to an apparently unrelated person (e.g., in order to maintain that he or she did not participate in the making of the false statement).

\section{CLERICAL OR SECRETARIAL SERVICES}

33. Subsection (9) provides that a person is not considered to have made or furnished, or participated in, assented to or acquiesced in the making of, a false statement solely because the person provided clerical services (other than bookkeeping services) or secretarial services relating to the statement.

34. For the purposes of the third-party civil penalties, clerical and secretarial duties do not include any involvement in the preparation of financial accounts. This is true, unless if it is of an administrative nature such as typing or formatting without having any regard to content other than the accurate reproduction of originals that are prepared by others. Bookkeeping services would include recording business accounts and transactions.

\section{GOOD FAITH RELIANCE}

35. Subsection (6) provides for an exception in the application of the third-party civil penalties for reliance in good faith. This exception provides that an advisor who acts on behalf of the other person (i.e. the person who could use the false statement for a purpose of the ITA/ETA) is not considered to have acted in circumstances amounting to culpable conduct relating to a false statement solely because:

- the advisor relied, in good faith, on information provided to the advisor by, or on behalf of, the other person; and

- because of such reliance, failed to verify, investigate, or correct the information (i.e., did not look into the accuracy of the information).

36. Good faith is described as "honesty of intention, and freedom from knowledge of circumstances which ought to put the holder on inquiry." The good faith reliance exception is available when the information used by the advisor or tax return preparer is not obviously unreasonable to a prudent person and does not raise questions in the 
mind of the advisor or tax return preparer. The good faith reliance exception is restricted to a person who acts on behalf of the other person, (i.e., taxpayer).

37. Per subsection (7), the reliance in good faith exception does not apply to a statement that a person makes in the course of an "excluded activity", as defined in paragraph 38 below. As a result, the good faith reliance exception is not applicable to a person who is selling or promoting, or accepting consideration for the promotion or sale of the arrangement.

\section{EXCLUDED ACTIVITY}

38. The definition of "excluded activity" is included in subsection (1). The term generally means the activity of promoting or selling (whether as a principal or agent, or directly or indirectly) an arrangement where it can reasonably be considered that the arrangement concerns a flow-through share, a tax shelter, or a tax-shelter like arrangement. It also includes accepting (whether as a principal or agent, or directly or indirectly) consideration for the sale of, or participation in, such an arrangement. Since tax shelters and flow through shares are not relevant for the purposes of GST/HST, these terms are not included in the definition of "excluded activity" in subsection $285.1(1)$ of the ETA.

39. Generally, the use of rollover provisions, estate freezes and other conventional taxplanning techniques are not considered excluded activities when the activity is carried on for a fee for a specific client. The client receives advice that is tailored to their facts, circumstances and needs. However, if a tax plan is prepared for a specific client and is subsequently promoted or sold to other clients, it may fall within the ambit of excluded activity since it would no longer be client-specific advice.

40. When an activity is an "excluded activity" the "in good faith" defense is not available. However, determination of whether the civil penalties would apply would still depend on the existence of a false statement and the knowledge thereof, or the reasonable expectation of such knowledge but for culpable conduct.

\section{TWO OR MORE FALSE STATEMENTS}

41. Subsection (8) treats two or more false statements made or furnished by a person in the course of one or more planning activities (or a valuation activity) as one false statement for the purpose of applying the planner penalty relating to the person's false statements. This is the case when a person made or furnished false statements in the course of one or more planning activities that are for a particular arrangement, entity, plan, property, or scheme or in the course of a valuation activity that is in respect of a particular property or service. For example, a tax-planning scheme could include two false statements, the over-valuation of property, and the overstatement of expenses. These two statements would be deemed to be one false statement for the purposes of applying the planner penalty. However, this treatment is not available for the application of the preparer penalty. Therefore, when the same false statement is used in the tax returns of more than one individual, a separate penalty would be 
applicable to the false statement in each return (subject to the other limits stated in subsection (5)).

\section{SPECIAL RULES FOR VALUATION ACTIVITIES}

42. Subsection (10) provides a special rule that applies to a statement made by a person who expresses an opinion on the value of a property or service (refer to as the "stated value") or by a person who uses that "stated value" in the course of an excluded activity. A statement as to the "stated value" is deemed to be a false statement that the person made in circumstances amounting to culpable conduct if the stated value is outside (either higher or lower than) a range of values.

43. The bottom of this range is created by the results of multiplying the prescribed percentage referred to in paragraph (10)(a) and the fair market value. The top of this range is created by the results of multiplying the prescribed percentage referred to in paragraph (10)(b) and the fair market value.

44. For example, assume that the prescribed percentage in paragraph (10)(a) is $75 \%$, and the fair market value of a property used in an excluded activity is $\$ 100,000$. The lower limit of the range would be $100,000 \times 75 \%=75,000$. Assume the prescribed percentage in paragraph (10)(b) is $133 \%$. The upper limit of the range would be $100,000 \times 133 \%=133,333$. The resulting range, in this case, would be $\$ 75,000$ to $\$ 133,333$.

45. Despite the facts used in the above example, note that the regulations prescribing percentages have not yet been issued. If the stated value is in the range described in paragraph 43 , the onus is on the CCRA to prove the existence of a false statement made with knowledge or in circumstances amounting to culpable conduct. Factors to be considered in determining whether penalties would be assessed include factors such as those listed in paragraph 67. However, if the stated value is outside of the range, the reverse onus rule applies.

\section{REVERSE ONUS RULE}

46. As stated in the preceding paragraph, if the stated value of a property or service lies outside the range, a "reverse onus" rule will apply, which means the valuation will be deemed to be a false statement made with culpable conduct unless the person establishes that the valuation was reasonable in the circumstances and made in good faith and not based on unreasonable or misleading assumptions.

47. Until the prescribed percentages are stipulated by the regulations, the deeming provision is not effective. This means the CCRA will have to demonstrate that a false statement was made either knowingly, or in circumstances amounting to culpable conduct. 


\section{MULTIPLE ASSESSMENTS}

48. Subsection (12) provides rules for the purpose of applying the third-party civil penalty rules in section 163.2 of the ITA or section 285.1 of the ETA to a person.

49. First, paragraph (12)(a) concerns cases in which a person is assessed a planner penalty at a particular time regarding a specific planning or valuation activity and another assessment of the penalty is made at a later time regarding the same activity. If the penalty is reassessed because the gross entitlements of the person are greater at the subsequent time, then under subparagraph (12)(a)(i) the reassessment of the penalty at that later time is considered to be a separate penalty (for an example see paragraph 51). In any other case, the notice of assessment of the earlier penalty is deemed not to have been sent for the purpose of applying section 163.2 of the ITA or section 285.1 of the ETA (see subparagraph (12)(a)(ii)). This deeming provision is relevant in the calculation of the gross entitlements for the purpose of that later assessment. The calculation is provided for in paragraph $(12)(\mathrm{b})$.

50. Paragraph (12)(b) excludes certain amounts from a person's gross entitlements (in respect of a planning or a valuation activity in which there is a false statement made or furnished by the person). In general, this rule operates to base each assessment of a penalty under the planner penalty for a false statement on the gross entitlements of the person not counted in calculating the amount of the person's penalty(ies) previously assessed for the false statement. However, when subparagraph (12)(a)(ii) applies (i.e., the first notice of assessment is deemed not to have been sent), paragraph (12)(b) does not apply to reduce the amount of the second assessment since the original notice of assessment is deemed not to have been sent. As a result, the penalty amount on the second assessment in that case is based on the person's total gross entitlements at the time the notice of that assessment is sent.

51. As an example, presume that a person is assessed a planner penalty at a particular time in the amount of $\$ 10,000$, which represents the amount of the person's gross entitlements from a planning activity at that time. At a later time, it is discovered that the person's gross entitlements from the same planning activity have increased to $\$ 25,000$ and another assessment of a penalty is made at that later time, under subsection (2) against the person. The effect of subparagraph (12)(a)(i) in these circumstances is to deem the second assessment to be the assessment of a second penalty, and the effect of paragraph $(12)(b)$ is to reduce the person's gross entitlements at the later time to $\$ 15,000$, in order to take into account the previous assessment of $\$ 10,000$. Thus the end result is that the person is liable to pay two penalties: one of $\$ 10,000$ as of the particular time, and another of $\$ 15,000$ as of the later time.

52. As another example, suppose that the facts are the same as above, except that at the time of the first assessment the person's gross entitlements were $\$ 700$. In that case, the person would have been assessed $\$ 1,000$ under paragraph (3)(a) at that time. When the person is assessed at the later time, paragraph $(12)(\mathrm{b})$ reduces the person's gross entitlements at that later time by $\$ 1,000$, the amount of the previous assessment 
of the penalty. As well, subparagraph (12)(a)(i) deems the second assessment to be the assessment of a second penalty. In these circumstances, the person would be liable to pay a penalty of $\$ 1,000$ as of the time of the first assessment and would be liable to pay a second penalty of $\$ 24,000$ as of the later time.

53. In short, the amount of the gross entitlements used for the calculation of the second assessment is calculated by totalling the gross entitlements to date and reducing that amount by the penalty(ies) already assessed (and not vacated).

54. Subsection (12)(c) deals with the calculation of a preparer penalty. The amount of the gross compensation relating to the false statement is the total of the gross compensation to date less the amount of the preparer penalty already assessed (and not vacated).

\section{EXEMPTION FOR EMPLOYEES}

55. Subsection (15) provides that the third-party civil penalty provisions do not apply to an employee of the "other person" (i.e., the person who could use the false statement) referred to in the planner or preparer penalties. That is, an employee is protected by this exemption only for his employer's tax returns or information. The exemption in subsection (15) does not extend to employees who are engaged in excluded activities or who are specified employees (see paragraph 56). Under subparagraph (15)(b), the conduct of the employee is attributed to the employer for the purpose of applying subsection 163(2) of the ITA or subsection 285 of the ETA (the gross negligence penalties) to the employer.

56. "Specified employee" is defined in subsection 248(1) of the ITA to mean an employee of the person who is a specified shareholder of the person, or who does not deal at arm's length with the person. Essentially, a specified shareholder of a corporation is a person who owns, directly or indirectly, $10 \%$ or more of the issued shares of any class of the capital stock of the corporation or a related corporation.

57. For certain corporate groups, employees of one corporation maintain the accounting records and do tax-planning and tax return preparation for the entire corporate group. Such employees are not technically covered by the exemption provided in subsection (15) for their work related to other members of the corporate group. However, in such a situation, the CCRA would generally assess the preparer penalty against the employer and not the employee since the employee would be considered to have engaged in conduct that resulted in a penalty situation in the course of the employee's employment duties. This policy will also apply to other groups of organizations that have consolidated their accounting or tax functions in one of the member organizations.

\section{BURDEN OF PROOF}

58. Under subsection 163(3) of the ITA and subsection 285.1(16) of the ETA, the burden of proof of the applicability of the third-party civil penalties will lie with the CCRA. 
The standard of evidence used for these third-party penalties is the balance of probabilities with the benefit of the doubt going to the third-party (see paragraph 63 for additional comments). Specifically, there must be more evidence to indicate that the penalty should be applied than there is evidence to indicate that the penalty should not be applied.

\section{Other issues}

\section{PROFESSIONAL STANDARDS}

59. Professionals are expected to act in accordance with the code of ethics and rules of professional conduct of their governing bodies. The wording of the rules may differ but the professions generally require that their members not associate themselves with any information that they know, or should know, is false or misleading. The thirdparty civil penalty provisions do not impose a higher standard.

60. The accountants' Notice to Reader communication, as described in the CICA Handbook, is not considered to be an admission of indifference as to whether the ITA/ETA is complied with. In order for the civil penalties to apply, there must be a false statement made knowingly, or in circumstances amounting to culpable conduct. This determination would be made based on the facts. The Notice to Reader standard acknowledges that, generally, the public accountant is not required to make inquiries or perform other procedures to verify, corroborate or review information provided. However, when there are obvious inconsistencies, the public accountant may become aware that the information supplied is obviously incorrect, incomplete or otherwise unsatisfactory with the result that the financial statements may be false or misleading. In this case, he or she could be exposed to the civil penalties if additional or revised information was not requested and acted upon.

61. A disclaimer of the tax return preparer's responsibility for information received from the client does not absolve the preparer from the penalties if the conditions for applying the penalties exist (described in paragraphs 18 and 20).

62. Failure to meet professional standards that give rise to sanctions by professional bodies or financial liabilities to a client because of negligence or malpractice would not necessarily result in the application of the third-party civil penalties. Each situation will have to be considered individually before any penalty assessment occurs. The CCRA would still have to prove that the person knew, or would reasonably be expected to know, but for circumstances amounting to culpable conduct, that there is a false statement capable of being used for a purpose of the ITA/ETA.

63. As stated in paragraph 58, the burden of proof lies with the CCRA. The CCRA has to prove that an advisor or tax return preparer knew of the false statement or that culpable conduct existed in a given situation. This can only be established by reviewing the facts of the situation. Certain measures taken by an advisor or tax return preparer can assist the CCRA in determining whether the knowledge of a false 
statement or circumstancesamounting to culpable conduct existed in a given situation. These include a systematic approach to inquiring about questionable statements, following up and resolving such inquiries, and retaining evidence of such actions.

64. If a person exercises due diligence, the third-party penalty cannot be applied.

\section{APPLICATION OF THE LEGISLATION}

65. The third-party civil penalty provisions apply to statements made after June 29, 2000. The penalties may apply to any false statement made after this date. There is no statutory limitation regarding the time period during which an assessment of these penalties has to be issued.

66. When two or more persons are involved in the making of a false statement, the CCRA may apply the penalties to each of the persons. 67 . Whether penalties will be assessed in a given situation will depend upon the facts of the situation. Factors that may be relevant include:

- whether the false statement compromises the integrity of Canada's self assessment system of taxation by eroding the tax base;

- whether the false statement is widespread and/or abusive;

- whether the amount of taxes sought to be avoided by the taxpayer or by the other taxpayers affected by the false statement is significant;

- evidence to the effect that the advisor or tax return preparer or valuator has made false statements in the past;

- the advisor's knowledge of the taxpayer's business, financial, and/or personal circumstances; and

- experience of the advisor or tax return preparer.

\section{FALSE STATEMENTS IN PRIOR YEARS}

67. If an advisor or tax return preparer finds himself in a situation where he or she discovers that another person had made a false statement for tax purposes (e.g., he or she obtains a new client and finds that the previous accountant has made a false statement), the new advisor or tax return preparer would be expected to rectify the situation to the extent that the false statement affects the tax return of the current year. The advisor or preparer should advise his or her client to make a voluntary disclosure as described in Information Circular (IC) 00-1, Voluntary Disclosures Program, for the prior years or file amended returns for each of the affected years. If the client does not follow this advice, the advisor or preparer is not exposed to the third-party civil penalties in respect of prior years. If the current-year return not reflect the corrections because the taxpayer did not agree to it, and the advisor or 
preparer prepared the return knowing of the discrepancy, the advisor or preparer as well as the taxpayer may be subject to penalties. The advisor would be subject to the third-party civil penalties, and the taxpayer to a gross negligence penalty (subsection 163(2) of the ITA and section 285 of the ETA).

\section{PERSONS SUBJECT TO PENALTIES}

68. The CCRA will look closely at the source of culpable conduct to determine who should be subject to the penalties. Generally, the CCRA will seek to apply the penalties to the person(s) directly involved in causing the false statement to be made. A corporation acts through its officers. Subject to the exception for employees mentioned previously and described in subsection (15), if the officers knew of the false statement, or were reasonably expected to know but for culpable conduct, both they and the corporation might be exposed to the penalties. For example, a corporation may be engaged in planning and/or promoting or selling an abusive tax shelter with overvaluations or inflated costs. In the likely situation that these activities are conducted by the officers of the corporation, the officers and the corporation would be exposed to the third-party civil penalties. In another situation, an employee may be engaged in a situation subject to third-party penalties, without the knowledge of the employer. In this case only the employee will be subject to the penalties. It should be noted that subsection 163(2.9) of the ITA allows for a partnership to be assessed the third-party civil penalties as an entity. In a partnership, only those partners who are engaged in an activity subject to third-party penalties would be assessed a penalty rather than the other partners.

\section{PRICE ADJUSTMENT CLAUSE}

69. Interpretation Bulletin IT-169, Price Adjustment Clauses, states that when a property is transferred in a non-arm's length transaction, the parties often include a price adjustment clause in the covering agreement under which the parties may agree that if the CCRA determines that the fair market value of the property is greater or less than the price otherwise determined in the agreement, that price will be adjusted to take into account the excess or the shortfall, provided that all of the following conditions are met:

- The agreement reflects a bona fide intention of the parties to transfer the property at fair market value and arrives at that value for the purposes of the agreement by a fair and reasonable method.

- Each of the parties to the agreement notifies the CCRA by a letter attached to the return for the year in which the property was transferred

- that he or she is prepared to have the price in the agreement reviewed by the CCRA according to the price adjustment clause,

- that he or she will take the necessary steps to settle any resulting excess or shortfall in the price, and 
- that a copy of the agreement will be filed with the CCRA if and when demanded.

- The excess or shortfall in price is actually refunded or paid, or a legal liability therefore is adjusted.

70. If all the above conditions are met, there would not be a false statement made with actual knowledge or in circumstances amounting to culpable conduct. Hence, the third-party civil penalties would not be applicable.

\section{NOTICES OF OBJECTION AND APPEALS TO THE COURT}

71. If after careful consideration of the representations made by the third-party, it is decided that a third-party penalty is warranted and an assessment against the thirdparty is issued, the normal objection and appeal procedures will apply.

72. The role of the Appeals Branch is to carry out fair and impartial reviews of objections to the CCRA's assessments. In the event that the penalty is confirmed, the third-party has the option of appealing to the Tax Court of Canada and, as applicable, to higher courts.

73. There is no third-party penalty in the absence of a false statement. Where the taxpayer has filed a Notice of Objection relating to an assessment arising from a false statement (for which the planner or preparer has been penalized), the CCRA may hold the advisor's or tax return preparer's Notice of Objection in abeyance pending the outcome of the taxpayer's objection or appeal, if the following conditions are met:

- the assessment related to the false statement is already under objection by the taxpayer; and

- the advisor or tax return preparer has requested in writing that consideration of his or her objection be held in abeyance pending the outcome of his or her client's case.

\section{THE GENERAL ANTI-AVOIDANCE RULE}

74. The penalties are not intended to apply to arrangements by reason only of a determination that they are subject to the application of the General Anti Avoidance Rule (GAAR). The GAAR applies only if an arrangement is otherwise technically effective. This means that the particular filing position is based on true statements rather than false statements. Thus, the penalties cannot apply. However, if the courts have decided a GAAR case in favour of the Crown and an identical plan is then proposed by the advisor, the penalties may apply. 


\section{NON RESIDENTS}

75. The third-party civil penalties can be applied to non-resident advisors. For example, where a non-resident parent caused a Canadian company to file a return containing a false statement, the non-resident will be subject to the penalties.

\section{Process}

76. Should circumstances necessitating the consideration of the application of the thirdparty civil penalties arise, the CCRA intends to strictly control the application of these penalties. Procedural checks and balances are in place to ensure that no one person can direct the application of the penalties or otherwise inappropriately apply the penalties.

77. The audit and referral process requires senior management involvement of the field office and Headquarters to ensure that the penalties are appropriately applied.

78. When an auditor first considers the possibility of applying the third-party civil penalties and prior to any discussion with the affected third party, both the management of the field office and Headquarters will be consulted to determine whether to pursue the matter further.

79. After initial consultations with Headquarters the field office management will discuss the issue with the affected third-party. The purpose of these discussions will be to inform the third party that consideration is being given to applying the penalties and to solicit representations from the third party that could be included in a potential referral of the issue to Headquarters. Based on the information provided, field office management may determine the penalties are not warranted, and advise Headquarters accordingly. Alternatively, the issue, along with any representation received from the third party would be referred to Headquarters.

80. Headquarters will review the facts of each case before a penalty proposal is made to a third party. To this end, a Penalty Review Committee (PRC) at Headquarters will meet as necessary to consider third-party civil penalty referrals. The PRC will include, for the foreseeable future, senior representatives from the CCRA's Compliance Programs Branch and Policy and Legislation Branch, and representatives from the Departments of Finance and Justice.

81. Subsequent to the issuance of a proposal letter, the CCRA will invite further written representations by, or on behalf of, the third party for consideration by the PRC.

82. The CCRA is prohibited by section 241 of the ITA and section 295 of the ETA from disclosing to the taxpayer any information relating to the advisor or tax return preparer. Consequently, at no time will the taxpayer be informed that the CCRA is gathering information to determine whether the taxpayer's advisor or tax return preparer could be subject to the third-party civil penalties. However, the CCRA will, 
in appropriate cases, gather information from all relevant sources including from a third party's client.

\section{Periodic Update}

83. The CCRA is committed to providing the tax community with periodic updates on the CCRA's experience in applying the penalties either directly at practitioner events, or through information provided to various groups in writing. 


\section{APPENDIX A - EXAMPLES}

The following examples consider only the possible application of the third-party penalties. As a result, we are limiting our comments. Any other tax issues that may arise out of these examples are not considered.

\section{EXAMPLE ONE: GOOD FAITH RELIANCE}

A newly acquired client, who is self-employed, brings to his accountant a listing of his business expenses. The client also provides the accountant with a figure for his total revenue. He instructs his accountant to prepare an income statement and his tax return based on this information. The accountant has a quick look at the expenses. The expenses seem to be related to the type of business of the client and nothing stands out as obviously unreasonable. After the client's income statement is prepared, it reflects $\$ 80,000$ of revenue and $\$ 55,000$ of expenses and the income tax return is filed on that basis.

Upon audit, the CCRA finds a large proportion of the expenses claimed cannot be substantiated by adequate documentation and may not have been incurred. Furthermore, the reported revenue is only half of actual revenue.

\section{COMMENTS}

There was nothing in the income statement that would have made the accountant question the validity of the information provided to him. Therefore, he could rely on the good faith defense and would not be subject to the preparer penalty.

\section{EXAMPLE TWO: RELIANCE IN GOOD FAITH ON ANOTHER PROFESSIONAL}

An accountant relies on the financial statements prepared by another professional accountant to report his client's self-employment income. The statements were not obviously unreasonable. The CCRA conducts an audit and discovers that the income statement contained material misrepresentations.

\section{COMMENTS}

Although the tax return contains one or more false statements, the accountant would be entitled to the good faith defense since he relied, in good faith, on information provided by another professional on behalf of the client that was not obviously wrong. Therefore, he would not be subject to the preparer penalty.

The third-party penalties may be applied to the other accountant if he knew or would be expected to know, but for circumstances amounting to culpable conduct, that the financial statements contained a false statement. 


\section{EXAMPLE THREE: HONEST ERROR}

Near the midnight deadline on April 30, a $\mathrm{T} 1$ is prepared and filed. Due to the hurry in meeting the statutory deadline, and confidence in the qualifications of the senior personnel who prepared the return, the return is filed without normal review. During an audit, it is discovered that carrying charges were misstated because of an apparent recording error. The actual amount of $\$ 1,098$ was claimed as $\$ 10,098$.

\section{COMMENTS}

The tax return preparer would not be subject to the third-party penalties. While the preparer might have been negligent in making the error, his actions were, in the circumstances, neither tantamount to intentional conduct nor was he showing an indifference as to whether the law was complied with.

\section{EXAMPLE FOUR: FAILURE TO ASK QUESTIONS}

An accountant who lives in an expensive neighbourhood notices that the house next door has just been sold. It was listed for $\$ 1$ million. The accountant introduces himself to the new neighbour and they become friends. At tax time the friend comes in and hires the accountant to prepare his return. The accountant is given a T4 with $\$ 25,000$ in income reported. Thinking that the gross income is on the low side, the accountant asks if this is all the income he has and the friend replies that it is so. The accountant does not ask any further questions but prepares and files the return. When the taxpayer is audited it is discovered that he has over $\$ 200,000$ in income.

\section{COMMENTS}

The accountant could be subject to the penalties for assisting in the understatement of a tax liability. The filing was highly suspect and even though the accountant asked one question, the response did not address the concern. An advisor or a tax return preparer who has knowledge of the personal circumstances of a client is expected to recognize obvious inconsistencies in the information provided by the client. In this case the accountant could not rely on the good faith defense. The accountant was in effect turning a "blind eye" to the false filing by not asking questions and obtaining plausible answers to the question of how the client could afford a house worth a million dollars despite having such a small income.

\section{EXAMPLE FIVE: INDIFFERENCE AS TO WHETHER THE TAX LEGISLATION IS COMPLIED WITH}

An accountant has several clients who have been reassessed for a tax shelter. The accountant knows that the CCRA is challenging the tax benefits claimed for the tax shelter on the basis that the shelter is not a business, is based on a significant overvaluation of the related property and, alternatively, is technically deficient. 
The Tax Court of Canada, in a test case (general procedure), denies deductions claimed for the tax shelter in a previous year by a client of the accountant. The client's appeal is dismissed. The case is not appealed and the accountant is aware of the Court's decision.

The accountant prepares and files a tax return on behalf of a different client that includes a claim for the same tax shelter that the Tax Court determined was ineffective.

\section{COMMENTS}

On these facts, the CCRA would consider assessing the accountant with the preparer penalty. However, if the accountant had determined, and was able to demonstrate that there was a reasonable basis upon which the Tax Court decision could be overturned by a higher court, the penalty would not apply.

\section{EXAMPLE SIX: INDIFFERENCE AS TO WHETHER THE ITA IS COMPLIED WITH}

A taxpayer approaches a tax return preparer to prepare and e-file his tax return. Prior to this, the tax return preparer and his firm did not provide any services to the taxpayer and they did not know each other.

The taxpayer provides the tax return preparer with a $\mathrm{T} 4$ slip indicating that the taxpayer has $\$ 32,000$ of employment income.

The taxpayer tells the tax return preparer that he made a charitable donation of $\$ 60,000$ but forgot the receipt at home. The taxpayer asks that the tax return preparer immediately prepare and e-file the tax return without obtaining the receipt.

\section{COMMENTS}

On these facts, if the tax return preparer were to prepare and e-file the taxpayer's return without obtaining the charitable donation receipt, the CCRA would consider assessing the tax return preparer with the preparer penalty. Given that the quantum of the deduction is so disproportionate to the taxpayer's apparent resources as to defy credibility, to proceed unquestioningly in this situation would show wilful blindness and thus an indifference as to whether the ITA/ETA is complied with.

\section{EXAMPLE SEVEN: TAX-SHELTER LIKE ARRANGEMENT}

A promoter sells a tax-shelter like arrangement to individual taxpayers involving 10,000 pieces of art.

Each taxpayer acquires one piece of art for its fair market value of $\$ 100$. The valuator is aware of this information but agrees to appraise each art piece at $\$ 1,000$.

Concurrently, the promoter solicits a registered charity that agrees to accept the art as charitable donations and issue a charitable donation receipt in the amount of the appraised 
value ( $\$ 1,000$ per artwork). This charity immediately auctions off the art to the highest bidder, and the price paid reflects the $\$ 100$ value per piece.

A tax return preparer, who does not have any direct knowledge of the false statement, prepares the income tax return of his client, who had acquired and donated art making use of the above-mentioned arrangement.

The CCRA conducts a review of the client's return and determines that it contains a false statement (the overvaluation of the property donated).

\section{COMMENTS}

The promoter organized an arrangement that he or she knew included a false statement (e.g., about both the $\$ 100$ value of the art and the issuance of $\$ 1,000$ charitable donation receipts) and is, therefore, liable to the penalties.

The valuator has furnished false statements knowingly relating to the arrangement and is liable to the penalties unless he can prove the stated value was reasonable in the circumstances and that the statement was made in good faith.

If the charity knew, or would have reasonably been expected to know but for circumstances amounting to culpable conduct, that the valuations were incorrect, it would be liable for the penalties for issuing false receipts.

Although the tax return did contain a false statement, the tax return preparer did not know of the false statement, nor would he reasonably be expected to know but for circumstances amounting to culpable conduct. As a result, the preparer would not be assessed a thirdparty civil penalty.

\section{EXAMPLE EIGHT: PERSONAL EXPENSE RECORDED AS BUSINESS EXPENSE}

An accountant receives a box of personal and business receipts from his client and agrees to prepare a business expense statement for him. The accountant includes the $\$ 10,000$ cost of the client's family vacation (which he knew to be a non-deductible personal expense) as a business expense in the client's tax return.

The accountant prepares and finalizes the client's tax return and advises the client that he will be receiving a $\$ 5,000$ tax refund. The client files the tax return.

The CCRA conducts an audit and discovers the $\$ 10,000$ of personal expenses deducted in the client's tax return. The auditor also discovers that the families of the accountant and the client vacationed together. Therefore, the accountant knew the expense was personal at the time he included it in the business expenses. 


\section{COMMENTS}

The CCRA would consider assessing the accountant with the preparer penalty because the return was prepared and filed despite his knowledge of the false statement.

\section{EXAMPLE NINE: BONUS DOWN TO SMALL BUSINESS DEDUCTION LIMIT}

Xco is a small business, usually with less than $\$ 200,000$ annual income. When preparing financial statements, the external accountant determines taxable income to be $\$ 250,000$ and books a bonus payable of $\$ 50,000$ to be paid after the year end to the principal shareholder-manager. The tax return is prepared and filed on this basis since the general practice of the corporation is to distribute the profits in the form of bonuses.

\section{COMMENTS}

In general, the CCRA does not challenge the reasonableness of salaries and bonuses paid to the principal shareholder-managers of a corporation when: (a) the general practice of the corporation is to distribute the profits of the company to its shareholder-managers in the form of bonuses or additional salaries; or (b) the company has adopted a policy of declaring bonuses to the shareholders to remunerate them for the profits the company has earned that are, in fact, attributable to the special know-how, connections, or entrepreneurial skills of the shareholders.

Bonuses paid to shareholders other than principal shareholder-managers will be subject to the normal test of reasonableness.

In view of the above, the preparer penalty would not apply.

\section{EXAMPLE TEN: SALARIES PAID TO FAMILY MEMBERS}

Financial statements and tax returns for Familyco are prepared by an accountant with a small practice. Familyco pays salaries to all family members, two of which are in University and one of which lives outside Canada. The taxpayer informs the accountant that the family meets a few times a year to discuss company business.

\section{COMMENTS}

Generally, reasonableness of salaries to family members who provide services in the course of the business is not an issue that would be subject to the third-party civil penalties. In extreme situations these penalties may apply. Where family members have provided no services and the accountant knows this fact, third-party civil penalties would be considered.

If the accountant knew that no services were provided by the family members to Familyco, but filed the $T 2$ return that included a deduction for such payments, he would 
have participated in making a false statement and as such could be liable to a preparer penalty.

If the accountant did not know, but would be reasonably expected to know of the false statement, one needs to determine if the accountant's action resulted in culpable conduct. Facts to be considered with regard to whether the penalties will be applied include those listed in paragraph 67.

\section{EXAMPLE ELEVEN: INFLATED ROYALTIES}

A tax advisor is one of the partners in a firm that has a particular corporate client. The client has recently increased the royalty payments to its non-resident parent company as instructed by its parent company. The tax advisor suspects that the corporate client is deducting inflated royalties. The tax advisor discusses the concerns with a specialist in the firm who confirms the suspicions. Nonetheless, the tax advisor files the client's tax return based on this information, since the Vice-President of the corporate client alluded to the fact that its significant business could be taken to a competitor who is willing to file on that basis. None of the other partners in the partnership are aware of the tax advisor's actions.

\section{COMMENTS}

The tax advisor was very suspicious of the information provided by the client. By having his suspicions confirmed, the advisor arguably knew that there was a false statement and he participated in using the false statement for tax purposes. Therefore, applying the criteria listed in paragraph 67 to the facts, the CCRA would consider applying the preparer penalty to the tax advisor who participated in making the false statement and the gross negligence penalty (subsection 163(2) of the ITA and section 285 of the ETA) to the corporate client in whose return the false statement was made. As per paragraph 69, only the tax advisor involved in the making of the false statement would be assessed the third-party civil penalty rather than the other partners. The penalty amount is calculated in accordance with paragraph 21. Presumably, the gross compensation would be the fees from the amounts to which the tax advisor or partnership is entitled to receive for the activity.

\section{EXAMPLE TWELVE: ESTATE PLANNING}

An accountant refers his client to a tax practitioner who specializes in estate freezes. The client informs the tax practitioner that he purchased the shares of his company 20 years ago for \$2 million and that his accountant had told him that the shares were now worth $\$ 15$ million (based on a casual comment). The rollover was executed by the specialist using this information. A subsequent review by the CCRA shows that both the adjusted cost base (ACB) and the fair market value (FMV) were incorrect. The client had paid only $\$ 150,000$ for the shares. The other $\$ 1,850,000$ was to pay for the balance in the shareholder's loan account. It was also discovered that there was no systematic approach to determining the FMV of the shares. The CCRA's valuation determined that the FMV of the shares was $\$ 20$ million, and the valuation was not contested. 


\section{COMMENTS}

The tax specialist is involved in a planning activity as the term is defined in subsection (1) of the tax legislation. However, he is not involved in an excluded activity but in conventional tax-planning.

It is reasonable to expect that a tax practitioner specializing in estate freezes would request source documents or take other steps to verify the ACB of the shares prior to executing a rollover. The practitioner knew that the shares were acquired 20 years ago and that there was a good chance that the client did not know the meaning and implication of the term "ACB". Given the likelihood that the verbal answers he would get could be wrong, the practitioner would be exposed to the penalties without further corroborative evidence. With respect to the FMV of the shares, if the tax specialist had no reason not to believe the information given by the client or on the client's behalf, the specialist would not be exposed to the penalties since the good faith reliance defense would be available to the specialist.

The accountant, who provided the valuation opinion for the shares, could be subject to the penalties if the accountant knew that the valuation was false or would reasonably be expected to know that the valuation was false. This can only be determined by reviewing the facts. If the valuation is within the range described in paragraph 43 , then the CCRA is required to determine that there was a false statement made with knowledge or in circumstances amounting to culpable conduct. However, if the other hand the valuation is outside the range, then the accountant would be deemed to have made a false statement that he would reasonably be expected to know, but for circumstances amounting to culpable conduct, is a false statement. However, the accountant will be able to rely on the soundness of the assumptions used as a defense.

\section{EXAMPLE THIRTEEN: TRANSFER PRICING}

An advisor is responsible for the filing of returns of a group of related subsidiary companies. He is employed by one of the companies (a Canadian company) in the group. The transfer prices used have been provided by the foreign parent and may not be appropriate for Canadian income tax purposes. The internal advisor suspects that the transfer pricing may be incorrect but he doesn't know. He makes a request to each Canadian company to provide details of their pricing decisions. Some companies respond that they keep records for transfer pricing purposes in accordance with subsection 247(4) of the ITA, while others inform the internal advisor that although they do not keep records in accordance with subsection $247(4)$, they would be able to defend their transfer pricing decisions.

Upon audit of one of the Canadian companies, it is determined that the non-resident related supplier did not keep records in accordance with subsection 247(4) and the CCRA made an adjustment of more than $10 \%$ to the transfer prices. 


\section{COMMENTS}

Whether the penalties are applied would depend on whether there is culpable conduct. The criteria stated in paragraph 67 will be used to determine if the penalties are applicable. In the situation at hand, the advisor knew that certain members of the related group were not complying with the documentation requirements of subsection $247(4)$. While the internal advisor made some inquiries, he could have made some more, (e.g., discussions with the management of the affected Canadian companies). The employer of the internal advisor is at risk if his employee (the internal advisor) knew that the transfer prices were incorrect and the return was filed notwithstanding that knowledge.

Regarding the applicability of the employee exemption, the internal advisor is not an employee of the company that was reassessed. Therefore, in law, the subsection 163.2(15) exemption would not be available to the internal advisor. However, if a penalty were to be applied, it would not be applied to the internal advisor but to his employer as per paragraph 57.

The subsection 247(3) penalty applies to situations that are unreasonable. The CCRA would not normally consider applying a penalty under the third-party civil penalty provisions unless the unreasonable situation is extreme in quantum and methods used. In those cases, we would consider applying both the subsection 247(3) penalty on the taxfiler and the third-party penalties on the person advising or counselling on the transfer prices.

Regarding the application of the civil penalties to the non-resident personnel, the nonresident company (through its employees) appears to be the person that recommended or decided the transfer prices that were used by the Canadian company. Therefore it could be subject to the penalties as discussed in paragraph 76 .

\section{EXAMPLE FOURTEEN: ABUSIVE TAX SHELTER}

A company is selling units in a limited partnership tax shelter. The company had acquired software for $\$ 50,000$ on the open market and transferred it to the limited partnership on the same day for $\$ 10,000,000$. The prospectus prepared by the company states that the fair market value of the software is $\$ 10,000,000$ and is supported by an appraisal. The tax shelter is registered with the CCRA and is available as an investment opportunity in the current year. The company's gross entitlements are $\$ 2,000,000$.

The CCRA reviews the tax shelter and determines that the fair market value of the software on the day of transfer into the limited partnership is $\$ 50,000$. The appraisal supporting the $\$ 10,000,000$ value was prepared by an apparently independent appraiser. However, it was not prepared using normal valuation principles. The appraiser informed the CCRA that all his calculations were based on the assumptions and other relevant facts provided to him by the company. The appraiser was paid $\$ 75,000$ for the appraisal. 


\section{COMMENTS}

The prospectus prepared by the company contains a false statement (overstated fair market value of the software) that could be used for tax purposes. The company knew or would reasonably be expected to know that the fair market value of the software was a false statement. Since the company is engaged in an excluded activity, it cannot rely on the good faith defense with respect to the valuation. The CCRA would consider assessing the company with third-party penalties in the amount of $\$ 2,000,000$. The CCRA would also consider assessing the appraiser with third-party civil penalties. The amount of the penalty would be his gross entitlements from the valuation activity, which is $\$ 75,000$.

\section{EXAMPLE FIFTEEN: ESTIMATED INFORMATION ON GST RETURN}

An annual GST return filer informs her accountant that she had not kept records of the GST paid or payable on her business purchases for the year. The accountant informs her that he would make an ITC claim based on the financial statements of her business.

The accountant applies a factor of $7 / 107$ to all expenses shown in the income statement. This includes the cost of sales and all acquisitions shown in the balance sheet. The amounts are reasonable and have been incurred. The income statement includes a large amount of payroll expenses and interest expense on which GST is not paid or payable.

The cost of sales includes a large proportion of purchases that are zero-rated. The accountant applies the 7/107 factor to payroll, interest, and zero-rated purchases. This results in an over statement of input tax credits reported on the GST return.

\section{COMMENTS}

The factors in paragraph 67 would be considered in determining whether the preparer penalty would be applied. The accountant is expected to know that GST is not payable in respect of payroll expense, interest expense and zero-rated purchases. In filing a claim that includes the above items, the accountant made a false statement, either knowingly, or in circumstances amounting to culpable conduct. Consequently the CCRA would consider assessing the accountant with the third-party civil penalty, specifically, the preparer penalty.

\section{EXAMPLE SIXTEEN: PROMOTION INVOLVING FALSE STATEMENT}

A person is selling GST exemption cards to consumers. For a payment of $\$ 150$, a consumer would receive a card that states that the cardholder is entitled to purchase goods and services free of GST.

\section{COMMENTS}

The person selling the GST exemption cards is reasonably expected to know that the GST exemption card does not entitle the consumers to purchase goods and services free of tax. In providing such assurance and issuing the card, the person is making a false statement 
either knowingly or in circumstances amounting to culpable conduct. Consequently, the CCRA would consider assessing the person with the third-party civil penalties. Specifically, the planner's penalty since the false statement is not included in the tax return of another person. The person's gross entitlements are the total of all amounts he is entitled to collect from the sale of the GST exemption cards.

\section{EXAMPLE SEVENTEEN: UNREASONABLE ARGUMENT}

An organization is advocating that GST is unconstitutional, and, therefore people should not pay, collect, or remit the GST. The organization makes presentations and publishes a number of publications containing statements of that nature.

\section{COMMENTS}

The statement that the GST is unconstitutional is clearly a false statement. A person would know or would reasonably be expected to know that the statement is a false statement. The CCRA would consider assessing the person who has made the false statement with the third-party civil penalty. In the absence of gross entitlements (e.g., revenues from the sale of publications containing false statements), the minimum penalty amount of $\$ 1,000$ would apply. 


\section{APPENDIX 2 \\ Section 163.2 of Income Tax Act (Canada) Misrepresentation Of A Tax Matter By A Third Party}

163.2(1) Definitions - The definitions in this subsection apply in this section.

"Culpable Conduct" means conduct, whether an act or a failure to act, that

(a) is tantamount to intentional conduct;

(b) shows an indifference as to whether this Act is complied with; or

(c) shows a wilful, reckless or wanton disregard of the law.

"Entity" includes an association, a corporation, a fund, a joint venture, an organization, a partnership, a syndicate and a trust.

"Excluded Activity", in respect of a false statement, means the activity of

(a) promoting or selling (whether as principal or agent or directly or indirectly) an arrangement, an entity, a plan, a property or a scheme (in this definition referred to as the "arrangement")) where it can reasonably be considered that

subsection $66(12.68)$ applies to the arrangement,

(ii) the definition "tax shelter" in subsection 237.1(1) applies to a person's interest in the arrangement, or

(iii) one of the main purposes for a person's participation in the arrangement is to obtain a tax benefit; or

(b) accepting (whether as principal or agent or directly or indirectly) consideration in respect of the promotion or sale of an arrangement.

"False Statement" includes a statement that is misleading because of an omission from the statement.

"Gross Compensation" of a particular person at any time, in respect of a false statement that could be used by or on behalf of another person, means all amounts to which the particular person, or any person not dealing at arm's length with the particular person, is entitled, either before or after that time and either absolutely or contingently, to receive or obtain in respect of the statement.

"Gross Entitlements" of a person at any time, in respect of a planning activity or a valuation activity of the person, means all amounts to which the person, or another person 
not dealing at arm's length with the person, is entitled, either before or after that time and either absolutely or contingently, to receive or obtain in respect of the activity.

"participate" includes

(a) to cause a subordinate to act or to omit information; and

(b) to know of, and to not make a reasonable attempt to prevent, the participation by a subordinate in an act or an omission of information.

"Person" includes a partnership.

"Planning Activity" includes

(a) organizing or creating, or assisting in the organization or creation of, an arrangement, an entity, a plan or a scheme; and

(b) participating, directly or indirectly, in the selling of an interest in, or the promotion of, an arrangement, an entity, a plan, a property or a scheme.

"Subordinate", in respect of a particular person, includes any other person over whose activities the particular person has direction, supervision or control whether or not the other person is an employee of the particular person or another person, except that, if the particular person is a member of a partnership, the other person is not a subordinate of the particular person solely because the particular person is a member of the partnership.

"Tax Benefit" means a reduction, avoidance or deferral of tax or other amount payable under this Act or an increase in a refund of tax or other amount under this Act.

"Valuation Activity" of a person means anything done by the person in determining the value of a property or a service.

(2) Penalty for misrepresentations in tax planning arrangements - Every person who makes or furnishes, participates in the making of or causes another person to make or furnish a statement that the person knows, or would reasonably be expected to know but for circumstances amounting to culpable conduct, is a false statement that could be used by another person (in subsections (6) and (15) referred to as the "other person") for a purpose of this Act is liable to a penalty in respect of the false statement.

(3) Amount of penalty - The penalty to which a person is liable under subsection (2) in respect of a false statement is

(a) where the statement is made in the course of a planning activity or a valuation activity, the greater of $\$ 1,000$ and the total of the person's gross entitlements, at the time at which the notice of assessment of the penalty is sent to the person, in respect of the planning activity and the valuation activity; and 
(b) in any other case, $\$ 1,000$.

(4) Penalty for participating in a misrepresentation - Every person who makes, or participates in, assents to or acquiesces in the making of, a statement to, or by or on behalf of, another person (in this subsection and subsections (5) and (6), paragraph 12(c) and subsection (15) referred to as the "other person") that the person knows, or would reasonably be expected to know but for circumstances amounting to culpable conduct, is a false statement that could be used by or on behalf of the other person for a purpose of this Act is liable to a penalty in respect of the false statement.

(5) Amount of penalty - The penalty to which a person is liable under subsection (4) in respect of a false statement is the greater of

(a) $\$ 1,000$, and

(b) the lesser of

the penalty to which the other person would be liable under subsection 163(2) if the other person made the statement in a return filed for the purposes of this Act and knew that the statement was false, and

the total of $\$ 100,000$ and the person's gross compensation, at the time at which the notice of assessment of the penalty is sent to the person, in respect of the false statement that could be used by or on behalf of the other person.

(6) Reliance in good faith - For the purposes of subsections (2) and (4), a person (in this subsection and in subsection (7) referred to as the "advisor") who acts on behalf of the other person is not considered to have acted in circumstances amounting to culpable conduct in respect of the false statement referred to in subsection (2) or (4) solely because the advisor relied, in good faith, on information provided to the advisor by or on behalf of the other person or, because of such reliance, failed to verify, investigate or correct the information.

(7) Non-application of subsec.(6) - Subsection (6) does not apply in respect of a statement that an advisor makes (or participates in, assents to or acquiesces in the making of) in the course of an excluded activity.

(8) False statements in respect of a particular arrangement - For the purpose of applying this section (other than subsections (4) and (5)),

(a) where a person makes or furnishes, participates in the making of or causes another person to make or furnish, two or more false statements, the false statements are deemed to be one false statement if the statements are made or furnished in the course of 
(i) one or more planning activities that are in respect of a particular arrangement, entity, plan, property or scheme, or

a valuation activity that is in respect of a particular property or service; and

(b) for greater certainty, a particular arrangement, entity, plan, property or scheme includes an arrangement, an entity, a plan, a property or a scheme in respect of which

an interest is required to have, or has, an identification number issued under section 237.1 that is the same number as the number that applies to each other interest in the property.

a selling instrument in respect of flow-through shares is required to be filed with the Minister because of subsection 66(12.68), or

one of the main purposes for a person's participation in the arrangement, entity, plan or scheme, or a person's acquisition of the property, is to obtain a tax benefit.

(9) Clerical services - For the purposes of this section, a person is not considered to have made or furnished, or participated in, assented to or acquiesced in the making of, a false statement solely because the person provided clerical services (other than bookkeeping services) or secretarial services with respect to the statement.

(10) Valuations - Notwithstanding subsections (6) and 163(3), a statement as to the value of a property or a service (which value is in this subsection referred to as the "stated value"), made by the person who opined on the stated value or by a person in the course of an excluded activity is deemed to be a statement that the person would reasonably be expected to now, but for circumstances amounting to culpable conduct, is a false statement if the stated value is

(a) less than the product obtained when the prescribed percentage for the property or service is multiplied by the fair market value of the property or service; or

(b) greater than the product obtained when the prescribed percentage for the property or service is multiplied by the fair market value of the property or service.

(11) Exception - Subsection (10) does not apply to a person in respect of a statement as to the value of a property or a service if the person establishes that the stated value was reasonable in the circumstances and that the statement was made in good faith and, where applicable, was not based on one or more assumptions that the person knew or would reasonably be expected to know, but for circumstances amounting to culpable conduct, were unreasonable or misleading in the circumstances. 
(12) Special rules - For the purpose of applying this section,

(a) where a person is assessed a penalty that is referred to in subsection (2) the amount of which is based on the person's gross entitlement at any time in respect of a planning activity or a valuation activity and another assessment of the penalty is made at a later time,

if the person's gross entitlements in respect of the activity are greater at that later time, the assessment of the penalty made at that later time is deemed to be an assessment of a separate penalty, and

in any other case, the notice of assessment of the penalty sent before that later time is deemed not to have been sent,

(b) a person's gross entitlements at any time in respect of a planning activity or a valuation activity, in the course of which the person makes or furnishes, participates in the making of or causes another person to make or furnish a false statement, shall exclude the total of all amounts each of which is the amount of a penalty (other than a penalty the assessment of which is void because of subsection (13)) determined under paragraph (3)(a) in respect of the false statement for which notice of the assessment was sent to the person before that time; and

(c) where a person is assessed a penalty that is referred to in subsection (4), the person's gross compensation at any time in respect of the false statement that could be used by or on behalf of the other person shall exclude the total of all amounts each of which is the amount of a penalty (other than a penalty the assessment of which is void because of subsection (13)) determined under subsection (5) to the extent that the false statement was used by or on behalf of that other person and for which notice of the assessment was sent to the person before that time.

(13) Assessment void - For the purpose of this Act, if an assessment of a penalty that is referred to in subsection (2) or (4) is vacated, the assessment is deemed to be void.

(14) Maximum penalty - a person who is liable at any time to a penalty under both subsections (2) and (4) in respect of the same false statement is liable to pay a penalty that is not more than the greater of

(a) the total amount of the penalties to which the person is liable at that time under subsection (2) in respect of the statement, and

(b) the total amount of the penalties to which the person is liable at that time under subsection (4) in respect of the statement. 
(15) Employees - Where an employee (other than a specified employee or an employee engaged in an excluded activity) is employed by the other person referred to in subsections (2) and (4),

(a) subsections (2) to (5) do not apply to the employee to the extent that the false statement could be used by or on behalf of the other person for a purpose of this Act; and

(b) the conduct of the employee is deemed to be that of the other person for the purposes of applying subsection 163(2) to the other person. 


\section{APPENDIX 3}

SPIRE FREEZERS

Structure Prior To Transactions

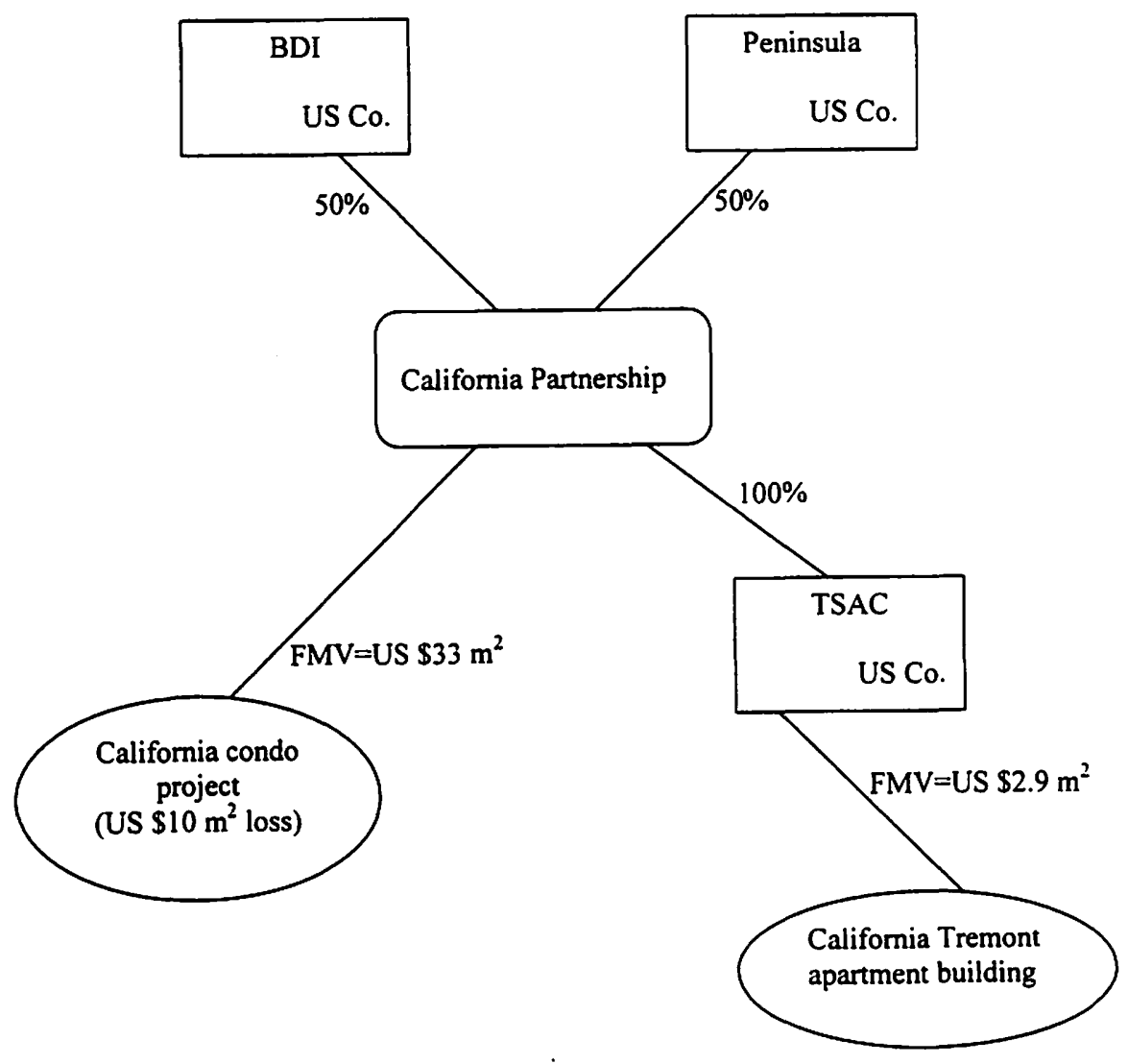




\section{APPENDIX 4}

SPIRE FREEZERS

\section{STRUCtURE AfTER Transactions}
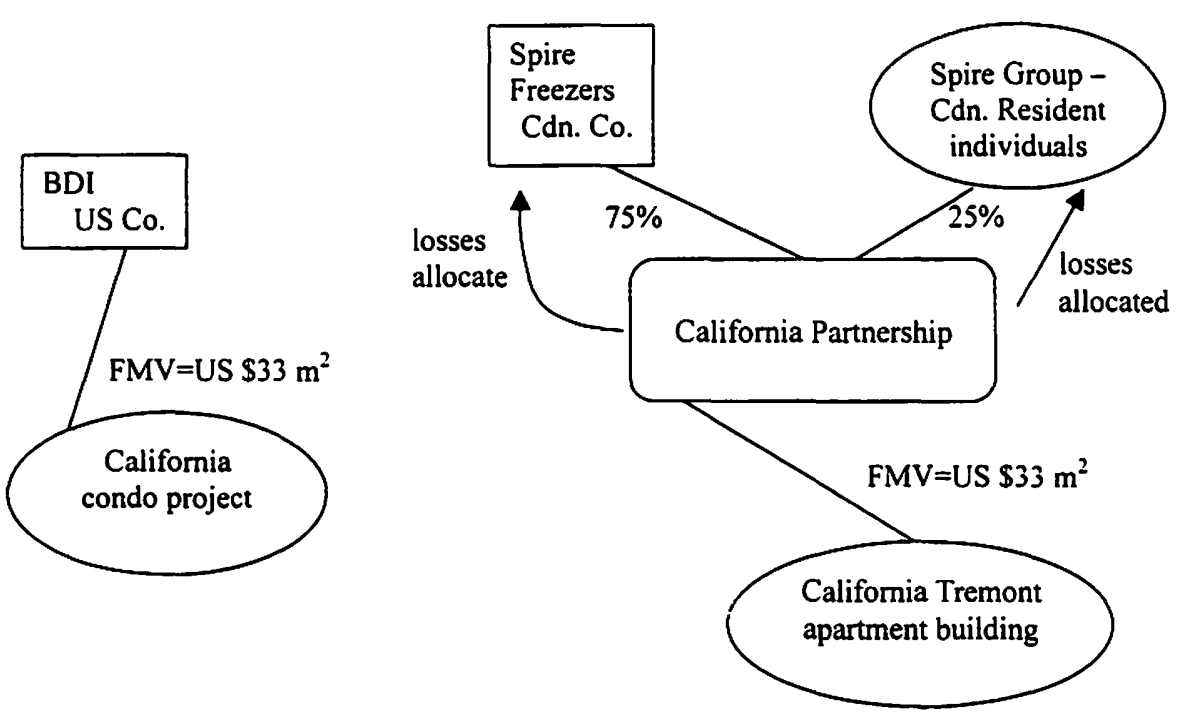